\title{
Defense In-Depth Accident Analysis Evaluation of Tritium Facility Bldgs. 232-H, 233-H, and 234-H
}

by

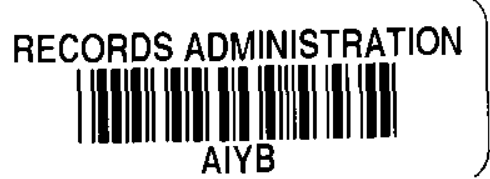

A. Blanchard

Westinghouse Savannah River Company

Savannah River Site

Aiken, South Carolina 29808

M. K. Gupta

WSMS

This paper was prepared in connection with work done under the above contract number with the U.S.

Department of Energy. By acceptance of this paper, the publisher and/or recipient acknowledges the U.S. Government's right to retain a nonexclusive, royalty-free license in and to any copyright covering this paper, along with the right to reproduce and to authorize others to reproduce all or part of the copyrighted paper. 


\section{DISCLAIMER}

This report was prepared as an account of work sponsored by an agency of the United States Government. Neither the United States Government nor any agency thereof, nor any of their employees, makes any warranty, express or implied, or assumes any legal liability or responsibility for the accuracy, completeness, or usefulness of any information, apparatus, product, or process disclosed, or represents that its use would not infringe privately owned rights. Reference herein to any specific commercial product, process, or service by trade name, trademark, manufacturer, or otherwise does not necessarily constitute or imply its endorsement, recommendation, or favoring by the United States Government or any agency thereof. The views and opinions of authors expressed herein do not necessarily state or reflect those of the United States Government or any agency thereof.

This report has been reproduced directly from the best available copy.

Available to DOE and DOE contractors from the Office of Scientific and Technical Information, P. O. Box 62, Oak Ridge, TN 37831; prices available from (423) 576-8401.

Available to the public from the National Technical Information Service, U. S. Department of Commerce, 5285 Port Royal Road, Springfield, VA 22161. 
Defense-in-Depth Accident Analysis Evaluation of Tritium Facility

Buildings 232-H, 233-H, and 234-H
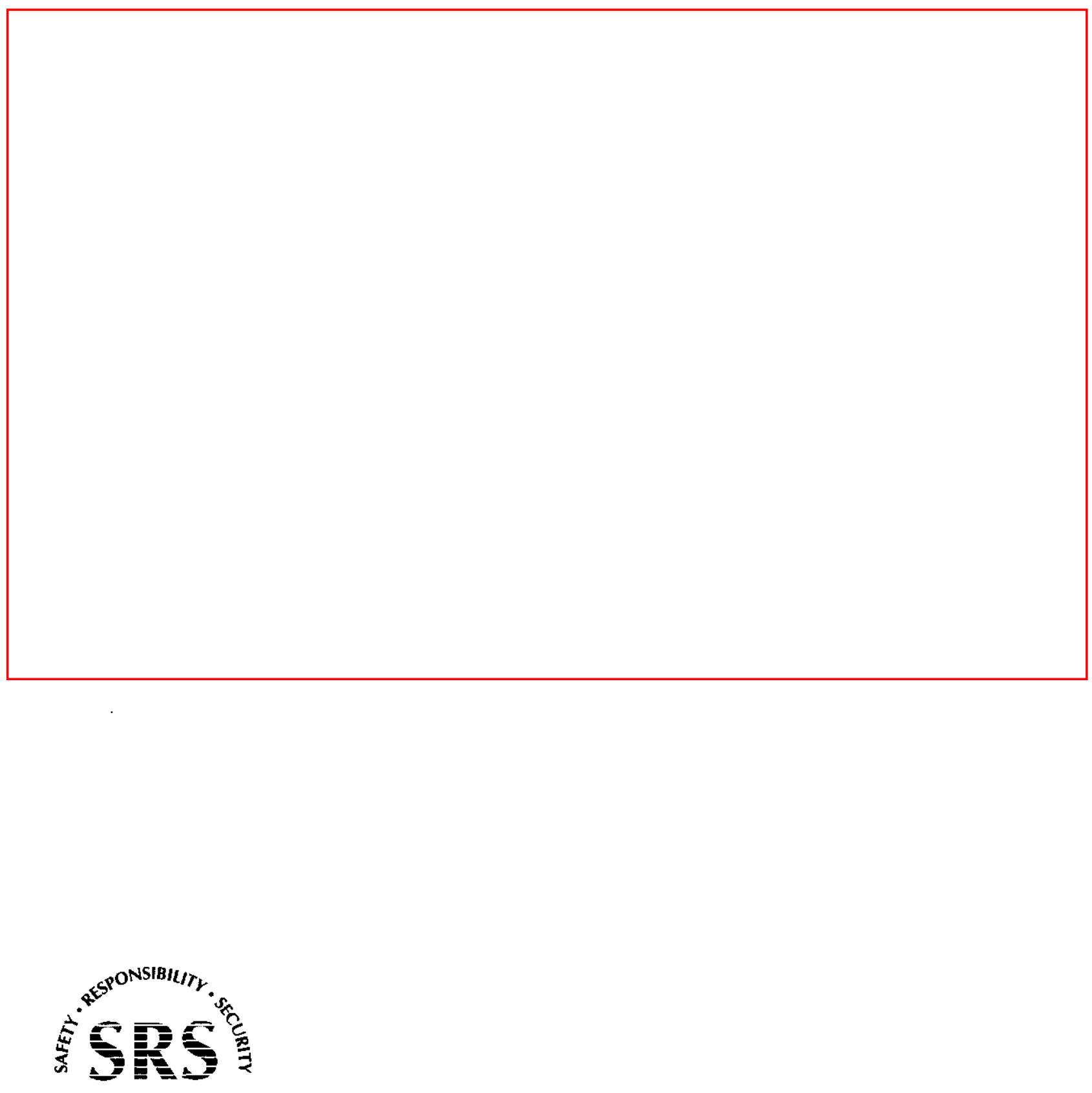

SAVANNAH RIVER SIYE

Westinghouse Savannah River Company

Savannah River Site

Aiken, South Carolina 29808 


\section{I.0 INTRODUCTION}

The primary purpose of this report is to document a Defense-in-Depth (DID) accident analysis evaluation for Department of Energy (DOE) Savannah River Site (SRS) Tritium Facility Buildings 232-H, 233-H, and 234-H. The purpose of a DID evaluation is to provide a more realistic view of facility radiological risks to the offsite public than the bounding deterministic analysis documented in the Safety Analysis Report, which credits only Safety Class items in the offsite dose evaluation.

The DID evaluation is performed in accordance with Authorization Basis (AB) Guidance Document 301-01.

The work documented in this report focuses on the draft SAR documented in Reference 1. The functional classification of these SRS Tritium Facility buildings is contained in Reference 2 .

The DID assessment is a team effort. The preparer of the report is a member of the team, who acted as a facilitator for the team meetings.

The Tritium DID evaluation specified by the procedure implementing AB Guidance Document 301-01. The Phase I credits the following: (1) SC items, (2) SS items, and (3) best-estimate analysis factors. The Phase II credits the following: (1) SC items, (2) SS items, (3) HA items, and (4) best-estimate analysis factors.

Additional supporting information is contained in Reference 3.

\subsection{ACCIDENTS AND EQUIPMENT}

The first column of Table 1, Offsite SC Results, lists the accidents for which quantitative accident analyses are documented in the Tritium SAR (Reference 1). In Table 1, these accidents are grouped by accident type.

Table 4 lists Safety Class (SC) and Safety Significant (SS) Systems, Structures, and Components (SSCs) credited in the hazard analysis and in the accident analysis for each of the events listed in Table 1. Table 4 also lists potential defense-in-depth items (BOLD underline) for each of the accidents listed in Table 1. (The information listed in Table 4 includes administrative controls in addition to SSCs.) The information in Table 4 is adapted from References 1 and 2.

The DID accident analysis evaluation involves an assessment by a team to (1) select DID items to reduce offsite doses and (2) develop dose reduction factors for each selected item, based on qualitative reasoning. 
Table 1 summarize the results of the SAR accident analysis (i.e., these are the pre-DIDevaluation starting points for the DID evaluation). The corresponding DID dose evaluation goals (EG) are also listed in Table 1. The estimated doses results by considering Safety Class (SC) items, and Best Estimate (BE) analysis for all three cases are in Table 1. There is no change in the frequencies of the scenario because the contribution of the SC items is already considered in the SAR analysis. The estimated high, medium and low doses are all below the DID evaluation goals (EG) (Ref. 3).

The medium doses calculated by considering $\mathrm{SC}$ items and $\mathrm{BE}$ methodology are below the $\mathrm{DID} E \mathrm{EG}$ as required by the $\mathrm{AB}$ guidance document 301-01.

The estimated doses results by considering Safety Significant (SS) items, SC items, and $\mathrm{BE}$ analysis for all three cases are in Table 2, Offsite SS Results. There is a change in the frequencies of some scenario as compared to the values in the SAR when the realistic contribution of the SS items is considered. The SS items/programs that reduce the frequency of a scenario are shown in Table 4 (in BOLD letters). The estimated high, medium and low doses are all below the DID evaluation goals (EG) (Ref. 3).

The medium doses calculated by considering SS items, SC items and BE methodology are below the DID EG as required by the AB guidance document 301-01.

The estimated doses results by considering Hazard Analysis (HA) items, SS items, SC items, and BE analysis for all three cases are in Table 3, Offsite HA Results. There is a change in the frequencies of some scenario as compared to the values calculated by SS and SC items when the realistic contribution of the HA items is considered. The HA items/programs that reduce the frequency of a scenario are shown in Table 4 (in BOLD letters). The estimated high, medium and low doses are all below the DID evaluation goals (EG) (Ref. 3).

\subsection{DEFENSE-IN-DEPTH EVALUATIONS}

The DID methodology is partly qualitative and relies on judgement to a certain extent.

This section contains a subsection summarizing the DID evaluation for each of the events in the SAR, with two exceptions. The exceptions are (1) the Building 234-H fire scenario that releases only mercury vapor (which is not a significant radiological release event) and (2) the 217-H explosion scenario (the SAR contains an evaluation of possible scenarios, but concludes that none of them are credible).

Each of the following DID evaluation subsections contains a brief description of the event scenarios. These scenarios were adapted (condensed) from descriptions in Reference 1. The following paragraphs are generic descriptive material that has also been adapted from Reference 1 . 
Fires were identified in all three frequency bins for building 232-H. The anticipated fires were postulated to be hood fires, ventilation system fires, and a control room fire. The hood fire applies to any hood in the building, including the Zeolite bed recovery hood, MTF hoods, and process hold tank hoods. The unlikely fires included single room fires, multi-room zone fires, multi-zone fires, and full area fires. The extremely unlikely fire is represented by a full building fire.

Fires were identified in all three frequency bins for building 234- $\mathrm{H}$. The anticipated fires were postulated to be hood fires or a fire in $217-\mathrm{H}$ vault involving inventory in one HIVES. The hood fire applies to any hood in the building, including both the hoods in the finishing areas and the hoods in the currently unused process areas. The unlikely fires include hood fires, single room fires, multi-room zone fires, and multi-zone fires. The extremely unlikely fires are represented by a fire in the $217-\mathrm{H}$ vault. It has been shown that fires which propagate through the walls separating the $217-\mathrm{H}$ vault from the rest of 234-H are beyond extremely unlikely events so long as the planned fire protection upgrades are completed.

Building 232-H is used for isotopic separation and purification of hydrogen isotopes and contains equipment for processing significant quantities of hydrogen gas. Two types of explosion events are analyzed for Building 232-H; pressurized process tank deflagration and process tank internal detonation. Pressurized process tank deflagration and Process tank internal detonation accidents are in the Unlikely and Extremely Unlikely frequency bin, respectively,

It should be noted that for all of the deflagration and detonation scenarios for building 232-H, a 3-atmosphere pressure limit has been assumed at the request of the facility. The intended effect of limiting the peak operating pressure is to reduce the likelihood of a detonation if a flammable mixture is ignited inside a tank. Although this assumption is partially responsible for moving the detonation accident from the Unlikely frequency bin to the Extremely Unlikely frequency bin, the 3 atmosphere limit is not necessary for meeting the evaluation guidelines since the detonation consequences are below the Unlikely guideline.

The accident selection process identified process related deflagrations and explosions as significant hazards for building 233-H. The explosion events in all three frequency bins are analyzed. They are: Loading Line deflagration in Anticipated category; Explosion in Environmental Conditioning area in Unlikely category, and Internal Mix Tank deflagration in Extremely Unlikely category.

The process tanks and piping in building 234-H have been blanked off and contain no more than $100 \mathrm{~g}$ of tritium contamination. The contamination is assumed to be distributed throughout the system so that the generation of flammable concentrations of hydrogen isotopes and air is not possible. The only other source of tritium is the reservoirs stored throughout building $234-\mathrm{H}$. The accident selection process identified process related deflagrations and explosions as significant hazards for building $234-\mathrm{H}$. The following two explosion events bound all the explosion events identified in the HA: 
Explosion Discharge of a Reservoir in Anticipated category and Explosion in Vault 217. $\mathrm{H}$ in Unlikely category.

Loss of confinement accidents identified in the accident selection process can be grouped into six accident types; leaks from process pipes and tanks, leaks from filled reservoirs, leaks from Zeolite beds, leaks from Zeolite bed recovery systems, contaminated pump oil spills, and contaminated mercury spills. Loss of confinement events are prerequisites for the explosion events discussed above. Thus, loss of confinement events discussed in this section do not include subsequent ignition, since that would place the accident in the explosion category.

Based on Tritium Data Bank information regarding reservoir releases and process leaks, loss of confinement accidents are anticipated events. The source terms associated with the events contained in the Tritium Data Bank were all relatively small. Loss of confinement events with large source terms require multiple failures and are expected to be unlikely events. The consequence associated with an elemental release of tritium is relatively benign, however, compared to a similar release of tritium oxide. Thus, process and reservoir leak loss of confinement events can be easily and conservatively bounded by non-mechanistic, large releases of elemental tritium without restricting facility operations.

A spill of tritiated water from a Zeolite bed, tritiated mercury, or tritiated pump oil, however, may lead to a direct release of tritium oxide. As stated in the frequency quantification calc-note, tritiated water releases from Zeolite beds are anticipated events. Unless a Zeolite bed is heated, as in Zeolite bed recovery operations, very little tritium oxide is released when a Zeolite bed container is breached. The simple room-temperature breach of a Zeolite bed will be bounded by a loss of Zeolite bed confinement during recovery operations.

\subsection{Building 232-H Hood Fire}

\subsubsection{Accident Description}

The worst hood fire in the anticipated frequency bin has been determined to place no more than $1.0 \mathrm{~kg}$ of tritium at risk. While more than $1.0 \mathrm{~kg}$ of tritium could be placed in a hood, the frequency of a fire in any specific hood (or any seven specific hoods) is in the Unlikely bin.

\subsubsection{Defense-in-Depth Evaluation}

The DID evaluation of this accident scenario is documented in Tables 1,2, and 3. The SAR analysis for this event does not meet the DID Evaluation Goals (EG). This event meets the DID EG by crediting the Safety Class (SC) items and Best Estimate (BE) analysis as shown in Table 1. Lower dose values are calculated (and are listed in Tables 
2 and 3 ) by crediting more realistic accident phenomena characteristics in addition to the SS and HA systems. The calculated medium dose is below the DID EG.

\subsection{Building 232-H Multiple Room/Fire Area Fire}

\subsubsection{Accident Description}

One Building 232-H fire area corresponds to Line III and the other corresponds to the rest of building $232-\mathrm{H}$. Nearly all of the tritium inventory is contained in a single fire area.

The bounding full area fire could start in one of the rooms in Zone 232-101c of 232-H. A possible place for it to start is in the electrical system in the control room for one of the Process Lines I or II. The fire is not initially detected by facility personnel and spreads to multiple rooms. The fire grows rapidly, flashes over from room to room and propagates throughout Zone 232-H-101c. The fire is assumed to stop at the fire barriers separating Zone 232-H-101c from Zones 232-H-101d and 232-H-101e. This places all inventory at risk in Process Lines I and II

In the above Unlikely scenario, the operation of the fire detection and suppression systems, facility worker training, and fire department response were credited to the level of reliability used to determine the fire frequency.

\subsubsection{Defense-in-Depth Evaluation}

The DID evaluation of this accident scenario is documented in Tables 1,2 , and 3 . The SAR analysis for this event does not meet the DID EG. This event meets the DID EG by crediting the $\mathrm{SC}$ items and $\mathrm{BE}$ analysis as shown in Table 1. Lower dose values are calculated (and are listed in Tables 2 and 3) by crediting more realistic accident phenomena characteristics in addition to the SS and HA systems. The calculated medium dose is below the DID EG.

\subsection{Building 232-H Full Facility Fire}

\subsubsection{Accident Description}

This scenario starts in the Zone 232-H-101c, as in the unlikely fire scenario described above. It propagates to fire Zone $232-\mathrm{H}-101 \mathrm{~d}$, then to fire Zone $232-\mathrm{H}-101 \mathrm{e}$ and finally to 232-H-101b (MTF). Process hoods are expected to topple or collapse, damaging equipment and piping and releasing process gas. Z-beds containing tritium oxide will likely release all their inventory as they are heated. The rooms and building structures will be at elevated temperatures for an extended period of time, since concrete will release absorbed heat long after the fire dies out. The entire tritium inventory in the building is at risk. 


\subsubsection{Defense-in-Depth Evaluation}

The DID evaluation of this accident scenario is documented in Tables 1,2, and 3. The SAR analysis for this event meets the DID EG. Lower dose values are calculated (and are listed in Tables 1,2, and 3) by crediting more realistic accident phenomena characteristics in addition to the SS and HA systems. The calculated medium dose is below the DID EG.

\subsection{Building 233-H Room Fire}

\subsubsection{Accident Description}

The anticipated fires are incipient fires which can be put out with a hand held fire extinguisher and are limited to the room of origin. Reservoirs may be randomly distributed throughout the facility and the risk associated with an incipient fire will be less than guidelines.

\subsubsection{Defense-in-Depth Evaluation}

The DID evaluation of this accident scenario is documented in Tables 1, 2, and 3. The SAR analysis for this event meets the DID EG. Lower dose values are calculated (and are listed in Tables 1, 2, and 3) by crediting more realistic accident phenomena characteristics in addition to the SS and HA systems. The calculated medium dose is below the DID EG.

\subsection{Building 233-H Multiple Room/Fire Area Fire}

\subsubsection{Accident Description}

The bounding unlikely fire in Building $233-\mathrm{H}$ is a fire area fire. The fire may start in the electrical equipment, wiring, or from random combustible material. In order for the fire to progress to an area fire, facility personnel must fail to detect the fire before it has progressed beyond the incipient stage and the sprinkler system must fail to control the fire to the room of origin.

\subsubsection{Defense-in-Depth Evaluation}

The DID evaluation of this accident scenario is documented in Tables 1, 2, and 3. . The SAR analysis for this event does not meet the DID EG. This event meets the DID EG by crediting the $\mathrm{SC}$ items and $\mathrm{BE}$ analysis as shown in Table 1. Lower dose values are calculated (and are listed in Tables 2 and 3 ) by crediting more realistic accident 
phenomena characteristics in addition to the SS and HA systems. The calculated medium dose is below the DID EG.

\subsection{Building 233-H Full Facility Fire}

\subsubsection{Accident Description}

The bounding extremely unlikely fire for building $233-\mathrm{H}$ is a full facility fire. The fire is similar to the unlikely fire described above but the fire department is not able to prevent the fire from crossing the room 11 wall. The fire spreads into the second fire zone and places the remainder of the building inventory at risk.

\subsubsection{Defense-in-Depth Evaluation}

The DID evaluation of this accident scenario is documented in Tables 1,2 , and 3. . The SAR analysis for this event does not meet the DID EG. This event meets the DID EG by crediting the $\mathrm{SC}$ items and $\mathrm{BE}$ analysis as shown in Table 1. Lower dose values are calculated (and are listed in Tables 2 and 3 ) by crediting more realistic accident phenomena characteristics in addition to the SS and HA systems. The calculated medium dose is below the DID EG.

\subsection{Building 234-H Hood Fire Releasing Tritium}

\subsubsection{Accident Description}

Building 234-H hoods in which tritium is allowed may be in any of several rooms associated with the finishing operations conducted in $234-\mathrm{H}$. The fires are incipient fires which are limited to the room of origin and are small enough to be put out with a hand held fire extinguisher. The incipient fire would not only have to compromise the confinement systems but also convert the escaping tritium to tritium oxide. It is not likely that an incipient fire will oxidize all of the escaping tritium but the release is clearly bounded by $100 \%$ oxidation of the entire inventory within the affected hood.

\subsubsection{Defense-in-Depth Evaluation}

The DID evaluation of this accident scenario is documented in Tables 1,2 , and 3 . The SAR analysis for this event does not meet the DID EG. This event meets the DID EG by crediting the $\mathrm{SC}$ items and $\mathrm{BE}$ analysis as shown in Table 1. Lower dose values are calculated (and are listed in Tables 2 and 3 ) by crediting more realistic accident phenomena characteristics in addition to the SS and HA systems. The calculated medium dose is below the DID EG. 


\subsection{Building 234-H Hood Fire Releasing Mercury}

\subsubsection{Accident Description}

This accident has no radiological consequences.

\subsection{Building 234-H Fire Area Fire}

\subsubsection{Accident Description}

The representative bounding fire in Building 234- $\mathrm{H}$ for the unlikely frequency bin is a full area fire in fire area 234-101. A fire is assumed to start in Zone 234-H-101a from a short in the electrical system. The propagation of the fire to the $217-\mathrm{H}$ vault is stopped by the fire wall. All of the tritium in loose reservoirs within $234-\mathrm{H}$ is at risk. In addition, the full area fire is considerably more severe than the test fire for the DOT certified class B shipping containers so the tritium in reservoirs within those containers is also at risk. It is estimated that the fire requires at least thirty three minutes to compromise all of the reservoirs in the various rooms within $234-\mathrm{H}$.

\subsubsection{Defense-in-Depth Evaluation}

The DID evaluation of this accident scenario is documented in Tables 1, 2, and 3. The SAR analysis for this event does not meet the DID EG. This event meets the DID EG by crediting the $\mathrm{SC}$ items and BE analysis as shown in Table 1. Lower dose values are calculated (and are listed in Tables 2 and 3) by crediting more realistic accident phenomena characteristics in addition to the SS and HA systems. The calculated medium dose is below the DID EG.

\subsection{Building 234-H 217-H Vault Fire (One HIVES)}

\subsubsection{Accident Description}

The representative bounding anticipated fire in $217-\mathrm{H}$ vault is a small, non-propagating fire. This scenario assumes that a fire could be initiated by welding activity, electrical equipment, flammable chemicals and gases, or general combustibles. Based on the design information (Ref. 1), current reservoir designs can withstand temperatures of $400^{\circ} \mathrm{F}$ or greater. The analysis in Reference 1 specifies the combustible loading for which the reservoirs will not be compromised in a fire. Therefore, a fire in the Vault $217-\mathrm{H}$ will not result in a release.

\subsection{Building 234-H/Vault 217-H Large Fire}




\subsubsection{Accident Description}

A fire in the $217-\mathrm{H}$ vault is the bounding extremely unlikely fire for building $234-\mathrm{H}$. This scenario assumes that sufficient transient combustibles have been brought into the $217-\mathrm{H}$ vault. The transient combustibles ignite and are not controlled by either direct personnel intervention or activation of the sprinkler system. The concrete fire barriers, however, successfully prevent the spread of the fire into the rest of Building 234-H. With the vault door closed and the ventilation system off, significant holdup of the hot gases would occur. Since the transient combustibles should be fairly limited, the duration and severity of the fire should be limited. All of the stored reservoirs (HIVES) would withstand $400^{\circ} \mathrm{F}$ without releasing any material because of their design and certain restrictions on the length of time since they were filled. HSVs are also expected to be stored in the HIVES in Vault 217-H but are not expected to release any tritium in the low severity fire postulated here since high temperatures are required to desorb tritium from an HSV. Therefore, a fire in the vault $217-\mathrm{h}$ will not result in a release.

\subsection{Building 232-H Pressurized Process Tank Internal Deflagration}

\subsubsection{Accident Description}

A number of product hold tanks of various sizes are located in Process Lines I and II. The largest of these is tank $246 \mathrm{~B}$ which has a volume of $2500 \mathrm{~L}$. Assuming that a 3 atmosphere pressure limit continues to be protected by rupture disks, the maximum amount of tritium that could be contained within tank $246 \mathrm{~B}$ at room temperature (i.e., 298 $\mathrm{K})$ is 307 moles $(3 * 2500 / 0.082 / 298=306.7)$. Under normal operation, this tank should never contain a flammable mixture of hydrogen and air. If, however, a transfer is being made to tank 246B and a leak develops on the suction side of the pump, air could be pumped into the tank along with hydrogen isotopes. If the operator does not detect this condition, an air leak of sufficient size to result in a flammable mixture of hydrogen isotopes and air within Tank 246B is possible. Assuming that an ignition source is available, the mixture could deflagrate, leading to high temperature reaction products and a sharp pressure rise inside the tank. Although the worst case pressure increase in the tank would result from a stoichiometric mixture of hydrogen and air, the 3 atmosphere pressure limit prevents the pressure increase from a stoichiometric deflagration from failing the process tank and piping. The largest source term, however, may result from the deflagration of a hyperstoichiometric mixture which does not burn all of the tritium in the tank but continues to oxidize tritium as the tank contents are vented into the hood. The bounding source term associated with a deflagration is postulated to result from a hyperstoichiometric deflagration within the tank which then blows down through the original leak in the pump. The unburned reactants and the hot product gases mix with the air in the hood and continue to oxidize. The rupture disk is conservatively assumed not to function so that the entire blowdown is released to the hood. 


\subsubsection{Defense-in-Depth Evaluation}

The DID evaluation of this accident scenario is documented in Tables 1, 2, and 3. The SAR analysis for this event does not meet the DID EG. This event meets the DID EG by crediting the $\mathrm{SC}$ items and $\mathrm{BE}$ analysis as shown in Table 1. Lower dose values are calculated (and are listed in Tables 2 and 3 ) by crediting more realistic accident phenomena characteristics in addition to the SS and HA systems. The calculated medium dose is below the DID EG.

\subsection{Building 232-H Process Tank Internal Detonation}

\subsubsection{Accident Description}

This event is similar to the process tank internal deflagration accident except that the pressure generated by the detonation will be significantly higher than that generated by the deflagration. Most of the tanks in $232-\mathrm{H}$ were designed to $150 \mathrm{psi}$ (10 atmospheres) so the maximum initial pressure of 3 atmospheres puts the $232-\mathrm{H}$ process tanks at risk of failure in a detonation event. The likelihood of a detonation in a flammable mixture increases as the mixture approaches stoichiometric concentrations and typically is only considered to occur for hydrogen/air mixtures between $18 \%$ and $60 \%$ hydrogen, although detonations in mixtures which were less than $18 \%$ hydrogen have also occurred. Given that the detonation may catastrophically fail the tank in which it occurs, shrapnel may be spread through the process area and compromise additional tanks and potentially create additional ignition hazards.

\subsubsection{Defense-in-Depth Evaluation}

The DID evaluation of this accident scenario is documented in Tables 1, 2, and 3 . The SAR analysis for this event meets the DID EG. Lower dose values are calculated (and are listed in Tables 1,2, and 3) by crediting more realistic accident phenomena characteristics in addition to the SS and HA systems. The calculated medium dose is below the DID EG.

\subsection{Building 233-H Loading Line Deflagration}

\subsubsection{Accident Description}

An explosion accident related to loading line operations is in the Anticipated frequency bin when the existing controls and equipment (especially the nitrogen glovebox atmosphere) for $233-\mathrm{H}$ loading lines are neglected. While the $233-\mathrm{H}$ event only affected a single reservoir during welding, other ignition sources exist in the $233-\mathrm{H}$ gloveboxes and an undetected leak or a misaligned valve could release a significant amount of tritium into the glovebox. At various times during the loading sequence, the loading manifold 
may be connected to mix tank through a bypass valve on the compressor. Thus, an undetected leak could result in the blowdown of a full mix tank to atmospheric pressure.

\subsubsection{Defense-in-Depth Evaluation}

The DID evaluation of this accident scenario is documented in Tables 1,2 , and 3 . The SAR analysis for this event does not meet the DID EG. This event meets the DID EG by crediting the $\mathrm{SC}$ items and $\mathrm{BE}$ analysis as shown in Table 1. Lower dose values are calculated (and are listed in Tables 2 and 3 ) by crediting more realistic accident phenomena characteristics in addition to the SS and HA systems. The calculated medium dose is below the DID EG.

\subsection{Building 233-H Explosion in Environmental Conditioning Area}

\subsubsection{Accident Description}

An explosion accident in Environmental Conditioning Area is in the Unlikely frequency bin. A worker error, improper maintenance, or a material or structural failure of a reservoir could initiate a tritium leak. The leaked tritium is subsequently ignited and released as tritium oxide. Although the reservoirs are generally quite robust, the durability of reservoirs outside of normal operating conditions is not currently available and any reservoirs in the room are conservatively assumed to fail when subjected to the explosion environment.

\subsubsection{Defense-in-Depth Evaluation}

The DID evaluation of this accident scenario is documented in Tables 1,2, and 3. The SAR analysis for this event meets the DID EG. Lower dose values are calculated (and are listed in Tables 1,2 , and 3) by crediting more realistic accident phenomena characteristics in addition to the SS and HA systems. The calculated medium dose is below the DID EG.

\subsection{Building 233-H Internal Mix Tank Deflagration}

\subsubsection{Accident Description}

The deflagration event for building $233-\mathrm{H}$ is an internal tank deflagration in the largest process tank, Mix Tank G. Since the mix tank is confined within a glovebox with a recirculating nitrogen atmosphere, the most likely deflagration occurs during open glovebox maintenance. Due to human errors during open glovebox maintenance, a mechanical breach of a process tank or the valve separating the tank from the manifold goes undetected and allows air to leak into the subatmospheric mix tank and form a flammable hydrogen/air mixture. The leak is conservatively assumed to occur in the 
largest mix tank in 233- $\mathrm{H}$ and an ignition source is assumed to ignite the mixture at the upper flammability limit. The peak deflagration pressure is well below the design pressure of the mix tanks so catastrophic failure of the tanks is not a concern. The tank pressure increases due to the deflagration and the product and unburned reactant gases expand back out into the room until the tank and room pressures are in equilibrium. As the hot gases expand into the room, the excess hydrogen isotopes mix with the room air and may form a secondary flammable region. Given the presence of hot combustion products, the secondary flammable regions are assumed to ignite and create additional tritium oxide. Rather than perform a complex analysis to determine the maximum amount of tritium oxide created from a particular set of initial conditions, a simplified bounding analysis will be used to determine the source term. The peak composition for a hyper-stoichiometric deflagration at initial conditions of room temperature and 1 atmosphere pressure was determined to be approximately $78 \%$ hydrogen isotopes-air.

\subsubsection{Defense-in-Depth Evaluation}

The DID evaluation of this accident scenario is documented in Tables 1, 2, and 3. The SAR analysis for this event meets the DID EG. Lower dose values are calculated (and are listed in Tables 1,2, and 3) by crediting more realistic accident phenomena characteristics in addition to the SS and HA systems. The calculated medium dose is below the DID EG.

\subsection{Building 234-H Explosive Discharge of a Reservoir}

\subsubsection{Accident Description}

The process tanks and piping in Building 234-H have been blanked off and contain no more than $100 \mathrm{~g}$ of tritium contamination. The only other source of tritium is the reservoirs stored throughout Building 234- $\mathrm{H}$. The explosion is caused by the operator error or explosive actuators (squib valves and explosive neutron generators).

\subsubsection{Defense-in-Depth Evaluation}

The DID evaluation of this accident scenario is documented in Tables 1, 2, and 3. The SAR analysis for this event meets the DID EG. Lower dose values are calculated (and are listed in Tables 1, 2, and 3) by crediting more realistic accident phenomena characteristics in addition to the SS and HA systems. The calculated medium dose is below the DID EG.

\subsection{Building 234-H Failure and Oxidation of Reservoirs}




\subsubsection{Accident Description}

The principal explosion hazard in Building 234-H involves failure of reservoirs caused by the overturning of a cart loaded with reservoirs. This event is similar to a loss of confinement accident with the addition of an ignition source being present. Although an extremely bounding assumption, the ignition source will be assumed to be present when the tritium is released from the reservoirs. The released gas is assumed to ignite and fully oxidize before the concentrations drop below the lower flammability limit

\subsubsection{Defense-in-Depth Evaluation}

The DID evaluation of this accident scenario is documented in Tables 1,2 , and 3 . The SAR analysis for this event does not meet the DID EG. This event meets the DID EG by crediting the $\mathrm{SC}$ items and $\mathrm{BE}$ analysis as shown in Table 1. Lower dose values are calculated (and are listed in Tables 2 and 3 ) by crediting more realistic accident phenomena characteristics in addition to the SS and HA systems. The calculated medium dose is below the DID EG.

\subsection{Building 232-H Pressurized Process Tank Leak}

\subsubsection{Accident Description}

For building 232-H, any loss of confinement event which releases elemental tritium, such as a process or reservoir leak, can be bounded by a total release of the process inventory as elemental tritium. The tritium inventory on Zeolite beds is not at risk for this accident since heat well in excess of that given off by tritium decay is required to drive significant amounts of tritium oxide off of the Zeolite beds. The inventory in reservoirs in MTF is also not included in the bounding release source term since it is physically separated from the process lines by the office areas of building $232-\mathrm{H}$, the total inventory is less than that of the process lines, and multiple independent failures are not likely.

\subsubsection{Defense-in-Depth Evaluation}

The DID evaluation of this accident scenario is documented in Tables 1, 2, and 3. The SAR analysis for this event meets the DID EG. Lower dose values are calculated (and are listed in Tables 1, 2, and 3) by crediting more realistic accident phenomena characteristics in addition to the SS and HA systems. The calculated medium dose is below the DID EG.

\subsection{Building 232-H Mercury Spill}




\subsubsection{Accident Description}

Tritiated mercury is stored in a 35 gallon stainless steel tank in room 164 of Building 232-H. Spills are anticipated occurrences and result in pools and droplets of mercury. The radiological source term from a spill of tritiated mercury is bounded by $2.0 \mathrm{Ci}$ of tritium oxide and is thus, negligible.

\subsubsection{Defense-in-Depth Evaluation}

The DID evaluation of this accident scenario is documented in Tables 1,2, and 3. The SAR analysis for this event meets the DID EG. Lower dose values are calculated (and are listed in Tables 1,2, and 3) by crediting more realistic accident phenomena characteristics in addition to the SS and HA systems. The calculated medium dose is below the DID EG.

\subsection{Building 232-H Z-bed recovery system leak}

\subsubsection{Accident Description}

Two Zeolite bed recovery loops are available and may be run simultaneously. The Zeolite beds are placed in furnaces and heated $\left(250^{\circ} \mathrm{C}\right)$ to drive off the adsorbed tritium oxide. The tritium oxide vapor then circulates through a heated magnesium bed which "cracks" the oxide to create elemental tritium and magnesium oxide. The recirculating gas stream is periodically vented to recovery tanks to relieve pressure in the recovery train and allow for mass spectrometer analysis. It is possible for both furnaces to connect to the same recovery loop. Thus, the postulated bounding accident is a leak upstream of the magnesium bed which allows tritium oxide from two heated Zeolite beds to escape the recovery system before passing through the magnesium bed. Part of the gas stream would still pass through the magnesium bed and only some fraction of the tritium oxide would be released to the hood. Rather than analyze the fluid flow in the recovery system to determine what fraction of the gas stream is released during recovery operations, a bounding source term was derived assuming that two 6 inch diameter Zeolite beds, at maximum historical loading, are being recovered using a single magnesium bed.

\subsubsection{Defense-in-Depth Evaluation}

- The DID evaluation of this accident scenario is documented in Tables 1,2, and 3. The SAR analysis for this event meets the DID EG. Lower dose values are calculated (and are listed in Tables 1,2, and 3) by crediting more realistic accident phenomena characteristics in addition to the SS and HA systems. The calculated medium dose is below the DID EG. 


\subsection{Building 233-H Process Tank Leak}

\subsubsection{Accident Description}

For building $233-\mathrm{H}$, any loss of confinement event which releases elemental tritium from a process tank or line, can be bounded by a total release of the inventory present in the largest process tank (2000 liter). The leak can be caused by worker error or mechanical failure (i.e., maintenance system) of components in the line or tank. The tritium inventory on Zeolite beds is not at risk for this accident since a significant amount of heat is required to drive the rather small tritium inventory off of the Zeolite beds. The inventory in reservoirs is also not included in the bounding release source term since it is physically separated from the process lines, represents a smaller quantity of tritium, and multiple independent failures must occur to release a significant amount of the reservoir inventory.

\subsubsection{Defense-in-Depth Evaluation}

The DID evaluation of this accident scenario is documented in Tables 1, 2, and 3. The SAR analysis for this event meets the DID EG. Lower dose values are calculated (and are listed in Tables 1, 2, and 3) by crediting more realistic accident phenomena characteristics in addition to the SS and HA systems. The calculated medium dose is below the DID EG. Based on the recommendation of the DID analysis Team, the following DID item is added:

- 233-H Glovebox Stripper System. The functioning of this system would preserve Tritium - the National Resource and minimize the tritium concentration in the gloveboxes and thus would minimize worker exposure during abnormal operations.

\subsection{Building 234-H Stripper System Leak}

\subsubsection{Accident Description}

The vast majority of the inventory in building $234-\mathrm{H}$ is contained in reservoirs. A small amount of tritium associated with the $100 \mathrm{~g}$ of contamination in the former process areas could also be in the stripper system. The former process areas of 234- $\mathrm{H}$ are also used for storage of deactivated pumps which contain residual amounts of tritiated mercury. The following bounding Anticipated loss of confinement event, stripper system leak, is analyzed for building 234-H.

For building 234-H, any loss of confinement event which releases tritium from inactive process systems, can be bounded by a release from stripper system. The leak can be caused by worker error, improper maintenance, or failure (i.e., material or structural) of stripper system. 


\subsubsection{Defense-in-Depth Evaluation}

The DID evaluation of this accident scenario is documented in Tables 1, 2, and 3. The SAR analysis for this event meets the DID EG. Lower dose values are calculated (and are listed in Tables 1,2, and 3 ) by crediting more realistic accident phenomena characteristics in addition to the SS and HA systems. The calculated medium dose is below the DID EG.

\subsection{Building 232-H MTF Collapse with a Secondary Fire}

\subsubsection{Accident Description}

The NPH events are common cause events and can effect the entire Tritium complex. Only two types of NPH events of significance were identified, tornadoes and earthquakes.

Generally, two levels of damage are considered for each building, an unlikely event in which the hazard curve is integrated up to the design basis event but few serious secondary events occur, and an extremely unlikely event in which the design basis event is followed by secondary events such as fires.

The natural phenomena hazards were treated in a probabilistic manner for buildings 232$\mathrm{H}$ and 234-H. The Building 233-H seismic scenarios are bounding scenarios that examine the maximum consequence if selected design features that mitigate the tritium release consequence in a seismic event are assumed to fail. Structural Engineering provided fragility values for the two buildings, significant equipment associated with the buildings, and the 295-H, 296-H, and 297-H stacks. The fragility values were input to a logic model for building and equipment failure. In addition, each damage state was considered to have secondary fires with a conditional probability of less than 0.1 . The secondary fires were assumed to be full area fires.

\subsubsection{Defense-in-Depth Evaluation}

The DID evaluation of this accident scenario is documented in Tables 1, 2, and 3. The SAR analysis for this event does not meet the DID EG. This event meets the DID EG by crediting the $\mathrm{SC}$ items and $\mathrm{BE}$ analysis as shown in Table 1. Lower dose values are calculated (and are listed in Tables 2 and 3) by crediting more realistic accident phenomena characteristics in addition to the SS and HA systems. The calculated medium dose is below the DID EG.

\subsection{Building 232-H MTF Collapse, Failure of High Risk Process Tanks with a Secondary Fire}




\subsubsection{Accident Description}

Section 3.24.1 contains a generic description of Tritium facility seismic events.

\subsubsection{Defense-in-Depth Evaluation}

The DID evaluation of this accident scenario is documented in Tables 1,2, and 3. The SAR analysis for this event meets the DID EG. Lower dose values are calculated (and are listed in Tables 1,2, and 3 ) by crediting more realistic accident phenomena characteristics in addition to the SS and HA systems. The calculated medium dose is below the DID EG.

\subsection{Building 233-H Evaluation Basis Seismic Event, No Fire}

\subsubsection{Accident Description}

Section 3.24.1 contains a generic description of Tritium facility seismic events.

\subsubsection{Defense-in-Depth Evaluation}

The DID evaluation of this accident scenario is documented in Tables 1,2, and 3. The SAR analysis for this event meets the DID EG. Lower dose values are calculated (and are listed in Tables 1, 2, and 3) by crediting more realistic accident phenomena characteristics in addition to the SS and HA systems. The calculated medium dose is below the DID EG. Based on the recommendation of the DID analysis Team, the following DID item is added:

- Seismic Tritium Confinement System (STCS). The functioning of this system in Building 233-H would preserve the National Resource Tritium and would minimize releases during a seismic event.

\subsection{Building 233-H Evaluation basis Seismic Event, Followed by a Fire}

\subsubsection{Accident Description}

Section 3.24.1 contains a generic description of Tritium facility seismic events.

\subsubsection{Defense-in-Depth Evaluation}

The DID evaluation of this accident scenario is documented in Tables 1,2, and 3. The SAR analysis for this event does not meet the DID EG. This event meets the DID EG by crediting the $\mathrm{SC}$ items and $\mathrm{BE}$ analysis as shown in Table 1. Lower dose values are 
calculated (and are listed in Tables 2 and 3) by crediting more realistic accident phenomena characteristics in addition to the SS and HA systems. The calculated medium dose is below the DID EG.

\subsection{Building 234-H Building Collapses, No Fire}

\subsubsection{Accident Description}

Section 3.24.1 contains a generic description of Tritium facility seismic events.

\subsubsection{Defense-in-Depth Evaluation}

The DID evaluation of this accident scenario is documented in Tables 1, 2, and 3. The SAR analysis for this event meets the DID EG. Lower dose values are calculated (and are listed in Tables 1,2 , and 3 ) by crediting more realistic accident phenomena characteristics in addition to the SS and HA systems. The calculated medium dose is below the DID EG.

\subsection{Building 234-H Building Collapses, Followed by a Fire}

\subsubsection{Accident Description}

Section 3.24.1 contains a generic description of Tritium facility seismic events.

\subsubsection{Defense-in-Depth Evaluation}

The DID evaluation of this accident scenario is documented in Tables 1,2 , and 3 . The SAR analysis for this event does not meet the DID EG. This event meets the DID EG by crediting the SC items and $\mathrm{BE}$ analysis as shown in Table 1. Lower dose values are calculated (and are listed in Tables 2 and 3 ) by crediting more realistic accident phenomena characteristics in addition to the SS and HA systems. The calculated medium dose is below the DID EG.

The compete list of SC, SS, and HA systems applicable to each accident is shown in Table 4 of this report. The DID systems are shown in italics in Table 4.

\subsection{SUMMARY OF CONCLUSIONS}

The estimated DID accident analysis doses are less than the DID Goal values. 


\subsection{REFERENCES}

1. WSRC, "Tritium Facilities Safety Analysis Report," WSRC-SA-1-2-VOL-1, DOE Review Draft A, July 1998.

2. WSRC, "Functional Classification Report for the Tritium Facilities," WSRC-TR-96-0158, Revision 2, July 1998.

3. Gupta, M. K., "Tritium Defense in Depth Evaluation, Buildings 232-H, 233-H, and 234-H (U)," S-CLC-H-00690, Revision 0. 


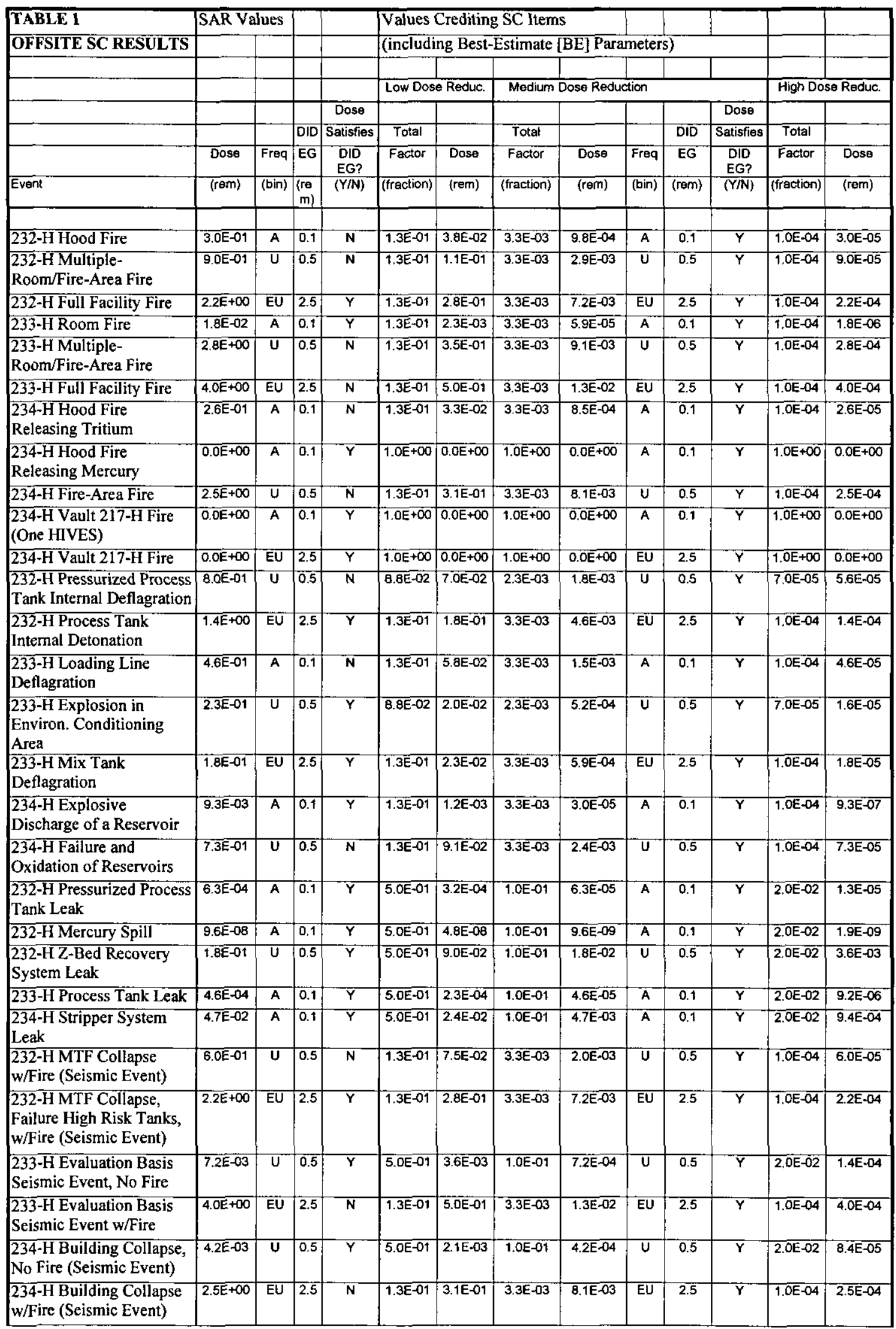




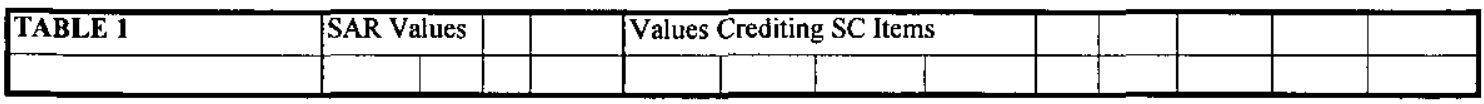

\begin{tabular}{|c|c|c|c|c|c|c|c|c|c|c|c|c|c|}
\hline \multirow{3}{*}{\begin{tabular}{l|} 
TABLE 2 \\
OFFSITE SS RESULTS \\
\end{tabular}} & \multicolumn{2}{|c|}{ SAR Values } & & & \multicolumn{8}{|c|}{ Values Crediting SC ltems (including BE Parameters) } & \\
\hline & & & & & \multicolumn{2}{|c|}{ and SS Items } & & & & & & & \\
\hline & & & & & & & & & & & & & \\
\hline & & & & & \multicolumn{2}{|c|}{ Low Dose Reduc. } & \multicolumn{5}{|c|}{ Medium Dose Reduction } & \multicolumn{2}{|c|}{ High Dose Reduc. } \\
\hline & & & & Dose & & & & & & & Dose & & \\
\hline & & & DID & Satisfies & Total & & Totai & & & DID & Satisfies & Total & \\
\hline & Dose & Freq & EG & $\begin{array}{l}\text { DID } \\
\text { EG? }\end{array}$ & Factor & Dose & Factor & Dose & Freq & EG & $\begin{array}{l}\text { DIID } \\
\text { EG? }\end{array}$ & Factor & Dose \\
\hline Event & (rem) & (bin) & $\left.\begin{array}{|c|c|}(r \theta \\
m\end{array}\right)$ & $(Y / N)$ & (fraction) & (rem) & \begin{tabular}{|l} 
(fraction) \\
\end{tabular} & (rem) & (bin) & $(\mathrm{r} \theta \mathrm{m})$ & (YIN) & $\mid$ (fraction) & (rem) \\
\hline & & & & & & & & & & & & & \\
\hline 232-H Hood Fire & $3.0 E-01$ & A & 0.1 & $\mathbf{N}$ & $1.3 \mathrm{E}-01$ & $3.8 E-02$ & $3.3 \mathrm{E}-03$ & $9.8 \mathrm{E}-04$ & A & 0.1 & $\mathbf{Y}$ & $1.0 \mathrm{E}-04$ & $3.0 \mathrm{E}-05$ \\
\hline $\begin{array}{l}\text { 232-H Multiple- } \\
\text { Room/Fire-Area Fire }\end{array}$ & $9.0 E-01$ & U & 0.5 & $\mathbf{N}$ & $1.3 \mathrm{E}-01$ & $1.1 \mathrm{E}-01$ & $3.3 E-03$ & $2.9 \mathrm{E}-03$ & v & 0.5 & $\bar{Y}$ & $1.0 E-04$ & $9 . \overline{\mathrm{E}-05}$ \\
\hline 232-H Full Facility Fire & $2.2 \mathrm{E}+\infty$ & EU & 2.5 & $Y$ & $1.3 \mathrm{E}-01$ & $2.8 \mathrm{E}-01$ & $3.3 \mathrm{E}-03$ & $7.2 \mathrm{E}-03$ & EU & 2.5 & $Y$ & $1.0 \mathrm{E}-04$ & $2.2 \mathrm{E}-04$ \\
\hline 233-H Room Fire & $1.8 \mathrm{E}-02$ & $\bar{A}$ & 0.1 & $\bar{Y}$ & $1.3 E-01$ & $2.3 E-03$ & $3.3 \mathrm{E}-03$ & $5.9 E-05$ & U & 0.5 & $\bar{Y}$ & $1.0 \mathrm{E}-04$ & $1.8 \mathrm{E}-06$ \\
\hline $\begin{array}{l}\text { 233-H Multiple- } \\
\text { Room/Fire-Area Fire }\end{array}$ & $2.8 \mathrm{E}+\infty$ & $\bar{U}$ & 0.5 & $\mathbf{N}$ & $1.3 \mathrm{E}-01$ & $3.5 E-0 t$ & $3.3 \mathrm{E}-03$ & $9.1 E-03$ & EU & 2.5 & $\bar{Y}$ & $1.0 \mathrm{E}-04$ & $2.8 E-04$ \\
\hline 233-H Full Facility Fire & $4.0 \mathrm{E}+00$ & EU & 2.5 & $\mathrm{~N}$ & $1.3 E-01$ & $5.0 \mathrm{E}-01$ & $3.3 \mathrm{E}-03$ & $1.3 \mathrm{E}-02$ & BEU & NA & $\bar{Y}$ & $1.0 \mathrm{E}-04$ & $4.0 E-04$ \\
\hline $\begin{array}{l}\text { 234-H Hood Fire } \\
\text { Releasing Tritium }\end{array}$ & $2.6 \mathrm{E}-01$ & $\bar{A}$ & 0.1 & $\mathrm{~N}$ & $1.3 E-01$ & $\overline{3.3 E-02}$ & $3.3 \mathrm{E}-03$ & $8.5 \mathrm{E}-04$ & A & 0.1 & $\bar{Y}$ & $1.0 \mathrm{E}-04$ & $2.6 \mathrm{E}-05$ \\
\hline $\begin{array}{l}\text { 234-H Hood Fire } \\
\text { Releasing Mercury }\end{array}$ & $\overline{0.0 E+00}$ & A & 0.1 & $\mathbf{Y}$ & $1.0 E+00$ & $0.0 \mathrm{E}+\infty$ & $1.0 \mathrm{E}+00$ & $0.0 E+\infty 0$ & $A$ & 0.1 & $\bar{Y}$ & $1.0 \varepsilon+\infty$ & $0.0 E+\infty$ \\
\hline 234-H Fire-Area Fire & $2.5 \mathrm{E}+\infty 0$ & $\mathrm{U}$ & 0.5 & $\mathbf{N}$ & $1.3 \mathrm{E}-01$ & $3.1 E-01$ & $3.3 E-03$ & $8.1 E-03$ & U & 0.5 & $\bar{Y}$ & $1.0 E-04$ & $2.5 \mathrm{E}-04$ \\
\hline $\begin{array}{l}\text { 234-H Vault 217-H Fire } \\
\text { (One HIVES) }\end{array}$ & $0.0 \mathrm{E}+00$ & $\bar{A}$ & 0.1 & $\bar{Y}$ & $1.0 E+\infty$ & $0.0 \mathrm{E}+00$ & $1.0 E+\infty 0$ & $0.0 E+\infty$ & A & 0.1 & $\bar{Y}$ & $1.0 E+00$ & $0.0 \mathrm{E}+00$ \\
\hline 234-H Vault $217-\mathrm{H}$ Fire & $0.0 \mathrm{E}+00$ & EU & 2.5 & $\mathbf{Y}$ & $1.0 E+\infty$ & $0.0 \mathrm{E}+00$ & $1.0 E+00$ & $0.0 E+00$ & EU & 2.5 & $\mathbf{Y}$ & $1.0 E+\infty$ & $0.0 \mathrm{E}+00$ \\
\hline $\begin{array}{l}\text { 232-H Pressurized Process } \\
\text { Tank Internal Deflagration }\end{array}$ & $8.0 E-01$ & $\bar{U}$ & 0.5 & $\mathrm{~N}$ & $8.8 E-02$ & $7.0 \mathrm{E}-02$ & $2.3 \mathrm{E}-03$ & $1.8 \mathrm{E}-03$ & $U$ & 0.5 & $\bar{Y}$ & $7.0 E-05$ & $5.6 \mathrm{E}-05$ \\
\hline $\begin{array}{l}\text { 232-H Process Tank } \\
\text { Internal Detonation }\end{array}$ & $1.4 E+\infty$ & EU & 2.5 & $Y$ & $1.3 \mathrm{E}-0 \mathrm{t}$ & $1,8 \mathrm{E}-01$ & $3.3 E-03$ & $4.6 E-03$ & BEU & NA & $\bar{Y}$ & $1.0 E-04$ & $1.4 \mathrm{E}-04$ \\
\hline $\begin{array}{l}\text { 233-H Loading Line } \\
\text { Deflagration }\end{array}$ & $4.6 \mathrm{E}-01$ & $A$ & 0.1 & $\mathbf{N}$ & $1.3 E-01$ & $5.8 E-02$ & $3.3 E-03$ & $1.5 \mathrm{E}-03$ & 0 & 0.5 & $\bar{Y}$ & $1.0 E-04$ & $4.6 \mathrm{E}-05$ \\
\hline $\begin{array}{l}\text { 233-H Explosion in } \\
\text { Environ. Conditioning } \\
\text { Area }\end{array}$ & $2.3 E-01$ & $\dot{U}$ & 0.5 & $\bar{Y}$ & $8.8 E-02$ & $2.0 \mathrm{E}-02$ & $2.3 E-03$ & $5.2 \mathrm{E}-04$ & BEU & NA & $\bar{Y}$ & $7.0 \mathrm{E}-05$ & $1.6 E-05$ \\
\hline $\begin{array}{l}\text { 233-H Mix Tank } \\
\text { Deflagration }\end{array}$ & $1.8 \mathrm{E}-01$ & EU & 2.5 & $\bar{Y}$ & $1.3 \mathrm{E}-01$ & $2.3 \mathrm{E}-02$ & $3.3 E-03$ & $5.9 E-04$ & EU & 2.5 & $\mathbf{Y}$ & $1.0 \mathrm{E}-04$ & $1.8 \mathrm{E}-05$ \\
\hline $\begin{array}{l}\text { 234-H Explosive } \\
\text { Discharge of a Reservoir }\end{array}$ & $9.3 \mathrm{E}-03$ & A & 0.1 & $\bar{Y}$ & $1.3 E-01$ & $1.2 \mathrm{E}-03$ & $3.3 E-03$ & $3.0 \mathrm{E}-05$ & A & 0.1 & $Y$ & $1.0 \mathrm{E}-04$ & 9.3E-07 \\
\hline $\begin{array}{l}234-\mathrm{H} \text { Failure and } \\
\text { Oxidation of Reservoirs }\end{array}$ & $7.3 E-01$ & iv & $\overline{0.5}$ & $\mathbf{N}$ & $1.3 \mathrm{E}-01$ & $9.1 E-02$ & $3.3 E-03$ & $2.4 E-03$ & $U$ & 0.5 & $\ddot{Y}$ & $1.0 \mathrm{E}-04$ & $7.3 E-05$ \\
\hline $\begin{array}{l}\text { 232-H Pressurized Process } \\
\text { Tank Leak }\end{array}$ & $6.3 E-04$ & $A$ & 0.1 & $\bar{Y}$ & $5.0 E-01$ & $3.2 \mathrm{E}-04$ & $1.0 \mathrm{E}-01$ & $6.3 E-05$ & U & 0.5 & $\bar{Y}$ & $2.0 \mathrm{E}-02$ & $1.3 E-05$ \\
\hline 232-H Mercury Spill & $9.6 E-08$ & A & 0.1 & $Y$ & $5.0 E-01$ & $4.8 E-08$ & $1.0 E-01$ & $9.6 E-09$ & A & 0.1 & $\mathrm{Y}$ & $2.0 E-02$ & $1.9 \mathrm{E}-09$ \\
\hline $\begin{array}{l}\text { 232-H Z-Bed Recovery } \\
\text { System Leak }\end{array}$ & $1.8 E-01$ & $U$ & 0.5 & $\mathbf{Y}$ & $5.0 E-01$ & $9.0 \mathrm{E}-02$ & $1.0 E-01$ & $1.8 \mathrm{E}-02$ & 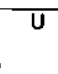 & 0.5 & $\bar{Y}$ & $2.0 E-02$ & $3.6 \mathrm{E}-03$ \\
\hline 233-H Process Tank Leak & 4.6E-04 & A & 0.1 & 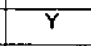 & $5.0 E-01$ & $2.3 E-04$ & $1.0 \mathrm{E}-01$ & $4.6 \mathrm{E}-05$ & A & 0.1 & $\mathbf{Y}$ & $2.0 \mathrm{E}-02$ & $9.2 \mathrm{E}-06$ \\
\hline $\begin{array}{l}\text { 234-H Stripper System } \\
\text { Leak }\end{array}$ & $4.7 E-02$ & A & 0.1 & $Y$ & $5.0 \mathrm{E}-01$ & $2.4 E-02$ & $1.0 \mathrm{E}-01$ & $4.7 E-03$ & $U$ & 0.5 & $\bar{Y}$ & $2.0 E-02$ & $9.4 \mathrm{E}-04$ \\
\hline $\begin{array}{l}\text { 232-H MTF Collapse } \\
\text { w/Fire (Seismic Event) }\end{array}$ & $6.0 \mathrm{E}-01$ & $U$ & 0.5 & $N$ & $1.3 \mathrm{E}-01$ & $7.5 E-02$ & $3.3 E-03$ & $2.0 \mathrm{E}-03$ & $u$ & 0.5 & $\bar{Y}$ & $1.0 \mathrm{E}-04$ & $6.0 \mathrm{E}-05$ \\
\hline $\begin{array}{l}\text { 232-H MTF Collapse, } \\
\text { Failure High Risk Tanks, } \\
\text { w/Fire (Seismic Event) }\end{array}$ & $2.2 E+\infty$ & EU & 2.5 & $\bar{Y}$ & $1.3 E-0 t$ & $2.8 E-01$ & $3.3 E-03$ & $7.2 \mathrm{E}-03$ & EU & 2.5 & $\bar{Y}$ & $1.0 \mathrm{E}-04$ & $2.2 \mathrm{E}-04$ \\
\hline $\begin{array}{l}\text { 233-H Evaluation Basis } \\
\text { Seismic Event, No Fire }\end{array}$ & $7.2 E-03$ & $U$ & 0.5 & $Y$ & $5.0 \mathrm{E}-01$ & $3 . \overline{6 E-03}$ & $1.0 E-0 t$ & $7.2 \mathrm{E}-0.4$ & U & 0.5 & $\bar{Y}$ & $2.0 E-02$ & $1.4 \mathrm{E}-04$ \\
\hline $\begin{array}{l}\text { 233-H Evaluation Basis } \\
\text { Seismic Event w/Fire }\end{array}$ & $4.0 E+00$ & EU & 2.5 & $\mathbf{N}$ & $1.3 E-01$ & $5.0 E-01$ & $3.3 E-03$ & $1.3 E-02$ & BEU & NA & $\bar{Y}$ & $1.0 E-04$ & 4.0E-04 \\
\hline
\end{tabular}




\begin{tabular}{|c|c|c|c|c|c|c|c|c|c|c|c|c|c|}
\hline \multirow{2}{*}{$\begin{array}{l}\text { TABLE } 2 \\
\text { 234-H Building Collapse, } \\
\text { No Fire (Seismic Event) }\end{array}$} & \multicolumn{2}{|c|}{ SAR Values } & \multirow[b]{2}{*}{0.5} & \multirow[b]{2}{*}{$Y$} & \multicolumn{8}{|c|}{ Values Crediting SC Items (including BE Parameters) } & \multirow[b]{2}{*}{$8.4 E-05$} \\
\hline & $4.2 E-03$ & $U$ & & & $5.0 \mathrm{E}-01$ & $2.1 \mathrm{E}-03$ & $1.0 \mathrm{E}-01$ & $4.2 \mathrm{E}-04$ & $\bar{U}$ & 0.5 & $Y$ & $2.0 \mathrm{E}-02$ & \\
\hline $\begin{array}{l}\text { 234-H Building Collapse } \\
\text { w/Fire (Seismic Event) }\end{array}$ & $2.5 E+00$ & EU & 2.5 & $\mathbf{N}$ & $1.3 \mathrm{E}-01$ & $3.1 \mathrm{E}-01$ & $3.3 E-03$ & $8.1 \mathrm{E}-03$ & EU & 2.5 & $\bar{Y}$ & $1.0 \mathrm{E}-04$ & $2.5 \mathrm{E}-04$ \\
\hline & & & & & & & & & & & & & \\
\hline
\end{tabular}

\begin{tabular}{|c|c|c|c|c|c|c|c|c|c|c|c|c|c|}
\hline \multirow{2}{*}{\begin{tabular}{|l} 
TABLE 3 \\
OFFSITE HA RESULTS \\
\end{tabular}} & \multicolumn{2}{|c|}{ SAR Values } & & & \multicolumn{8}{|c|}{ Values Crediting SC Items (including BE Parameters), } & \\
\hline & & & & & \multicolumn{4}{|c|}{ SS Items, and HA Items } & & & & & \\
\hline & & & & & \multicolumn{2}{|c|}{ Low Dose Reduc. } & \multicolumn{5}{|c|}{ Medium Dose Reduction } & \multicolumn{2}{|c|}{ High Dose Reduc. } \\
\hline & & & & Dose & & & & & & & Dose & & \\
\hline & & & DID & Satisfies & Total & & Total & & & DID & Satisfies & Total & \\
\hline & Dosese & Freq & EG & $\begin{array}{l}\text { DID } \\
\text { EG? }\end{array}$ & Factor & Dose & Factor & Dose & Freq & EG & $\begin{array}{l}\text { DID } \\
\text { EG? }\end{array}$ & Factor & Dose \\
\hline Event & (rem) & (bin) & $\begin{array}{c}\mathbf{r e} \\
\mathrm{m}\end{array}$ & $(\mathrm{Y} / \mathrm{N})$ & (fraction) & (rem) & (fraction) & (rem) & \begin{tabular}{|l} 
(bin) \\
\end{tabular} & (rem & $(\mathrm{Y} / \mathrm{N})$ & (fraction) & (rem) \\
\hline 232-H Hood Fire & $3.0 E-01$ & $\mathbf{A}$ & 0.1 & $N$ & $6.1 E-02$ & $1.8 \mathrm{E}-02$ & $8.1 \mathrm{E}-04$ & $2,4 E-04$ & U & 0.5 & $Y$ & $9.0 \mathrm{E}-06$ & $2.7 \mathrm{E}-06$ \\
\hline $\begin{array}{l}\text { 232-H Multiple- } \\
\text { Room/Fire-Area Fire }\end{array}$ & $9.0 \mathrm{DE}-01$ & $\bar{U}$ & 0.5 & $\mathbf{N}$ & $6.1 E-02$ & $5.5 E-02$ & $8.1 \mathrm{E}-04$ & $7.3 \mathrm{E}-04$ & $E U$ & 2.5 & $\mathrm{Y}$ & $9.0 \mathrm{E}-\infty$ & $8.1 \mathrm{E}-06$ \\
\hline 232-H Full Facility Fire & $2.2 E+00$ & EU & 2.5 & $\mathbf{Y}$ & $6.1 E-02$ & $1.3 \mathrm{E}-01$ & $8.1 \mathrm{E}-04$ & $1.8 \mathrm{E}-03$ & $\mathrm{BEU}$ & $\overline{\mathrm{NA}}$ & $\bar{Y}$ & $9.0 \mathrm{E}-06$ & $2.0 E-05$ \\
\hline 233-H Room Fire & $1.8 \mathrm{E}-02$ & A & 0.1 & $\bar{Y}$ & $\mid 8.8 E-02$ & $1.6 \mathrm{E}-03$ & $1.6 \mathrm{E}-03$ & 2.9E-05 & $\bar{u}$ & 0.5 & $\mathbf{Y}$ & $3.0 E-05$ & $5.4 E-07$ \\
\hline $\begin{array}{l}\text { 233-H Multiple- } \\
\text { Room/Fire-Area Fire }\end{array}$ & $2.8 \mathrm{E}+00$ & $\bar{U}$ & 0.5 & $\mathbf{N}$ & $\overline{8.8 E-02}$ & $2.5 E-01$ & $1.6 \mathrm{E}-03$ & $4.6 \mathrm{E}-03$ & EU & 2.5 & $\bar{Y}$ & $3.0 E-05$ & \begin{tabular}{|l|} 
8.4E-05 \\
\end{tabular} \\
\hline 233-H Full Facility Fire & $4.0 E+\infty$ & EU & 2.5 & $\mathbf{N}$ & $8.8 \mathrm{EE}-02$ & $3.5 E-01$ & $1.6 \mathrm{E}-03$ & $6.5 \mathrm{E}-03$ & BEU & NA & $\mathbf{Y}$ & $3.0 \mathrm{E}-05$ & $1.2 \mathrm{E}-04$ \\
\hline $\begin{array}{l}\text { 234-H Hood Fire Releasing } \\
\text { Tritium }\end{array}$ & $2 . \overline{\mathrm{GE}-01}$ & A & 0.1 & $\mathbf{N}$ & $6.1 \mathrm{E}-02$ & $1.6 \mathrm{E}-02$ & $8.1 \mathrm{E}-04$ & $2.1 E-04$ & U & 0.5 & $\bar{Y}$ & $9.0 \mathrm{E}-06$ & $2.3 E-06$ \\
\hline $\begin{array}{l}\text { 234-H Hood Fire Releasing } \\
\text { Mercury }\end{array}$ & $0.0 E+\infty$ & A & 0.1 & $\bar{Y}$ & $1.0 E+\infty$ & $0.0 \mathrm{E}+\infty$ & $1.0 \mathrm{E}+\infty$ & $0.0 E+00$ & U & 0.5 & $\mathrm{Y}$ & $1.0 \mathrm{E}+\infty$ & $0.0 E+\infty$ \\
\hline 234-H Fire-Area Fire & $2.5 E+00$ & $\bar{U}$ & 0.5 & $\mathbf{N}$ & $4.3 \mathrm{E}-02$ & $1.1 \mathrm{E}-01$ & $3.3 E-04$ & $8.1 \mathrm{E}-04$ & EU & 2.5 & $\bar{Y}$ & $1.8 \mathrm{E}-06$ & $4.5 \mathrm{E}-06$ \\
\hline $\begin{array}{l}\text { 234-H Vault } 217-H \text { Fire } \\
\text { (One HIVES) }\end{array}$ & $0.0 \mathrm{E}+00$ & A & 0.1 & $\mathrm{Y}$ & $1.0 E+\infty$ & $0.0 E+\infty$ & $1.0 \mathrm{E}+\infty$ & $\overline{0.0 E+00}$ & $u$ & 0.5 & $\mathbf{Y}$ & $1.0 \mathrm{E}+00$ & $0.0 \mathrm{E}+00$ \\
\hline 234-H Vault 217-H Fire & $0.0 E+00$ & EU & 2.5 & $\bar{Y}$ & $1.0 \mathrm{DE}+\infty$ & $0.0 E+00$ & $1.0 E+00$ & $0.0 E+00$ & BEU & NA & $\bar{Y}$ & $1.0 E+00$ & $0.0 E+\infty$ \\
\hline $\begin{array}{l}\text { 232-H Pressurized Process } \\
\text { Tank Intemal Deflagration }\end{array}$ & $8.0 E-01$ & $\mathrm{U}$ & 0.5 & $\mathbf{N}$ & $8.8 \mathrm{E}-02$ & $7 . \overline{0 E-02}$ & $2.3 E-03$ & $1.8 \mathrm{E}-03$ & $\mathrm{U}$ & 0.5 & $\mathrm{Y}$ & $7.0 E-05$ & $5.6 \mathrm{E}-05$ \\
\hline $\begin{array}{l}\text { 232-H Process Tank } \\
\text { Internal Detonation }\end{array}$ & $1.4 \mathrm{E}+00$ & EU & 2.5 & $\mathbf{Y}$ & $1.3 \mathrm{E}-01$ & $1.8 E-01$ & $3.3 E-03$ & $4.6 E-03$ & BEU & NA & $\mathbf{Y}$ & $1.0 E-04$ & $1.4 \mathrm{E}-04$ \\
\hline $\begin{array}{l}\text { 233-H Loading Line } \\
\text { Deflagration }\end{array}$ & $4.6 \mathrm{E}-01$ & A & 0.1 & $\mathbf{N}$ & $1.3 \mathrm{E}-01$ & $5.8 \mathrm{E}-0 \overline{2}$ & $3.3 E-03$ & $1.5 \mathrm{E}-03$ & EU & 2.5 & $\mathbf{Y}$ & $1.0 \mathrm{E}-04$ & $4.6 E-05$ \\
\hline \begin{tabular}{|l} 
233-H Explosion in \\
Environ. Conditioning Area
\end{tabular} & $2.3 E-01$ & $\bar{u}$ & 0.5 & $\bar{Y}$ & $6.1 E-02$ & $1.4 \mathrm{E}-02$ & $1.1 \mathrm{E}-03$ & $2.6 \mathrm{E}-04$ & BEU & NA & $\bar{Y}$ & $2.1 \mathrm{E}-0.5$ & $4.8 \mathrm{E}-06$ \\
\hline $\begin{array}{l}\text { 233-H Mix Tank } \\
\text { Deflagration }\end{array}$ & $1,8 E-01$ & EU & 2.5 & $\bar{Y}$ & $1.3 \mathrm{E}-01$ & $2.3 \mathrm{E}-02$ & $3.3 \mathrm{E}-03$ & $5.9 \mathrm{E}-04$ & EU & 2.5 & $\bar{Y}$ & $1.0 \mathrm{E}-04$ & $1.8 \mathrm{E}-05$ \\
\hline $\begin{array}{l}\text { 234-H Explosive Discharge } \\
\text { of a Reservoir }\end{array}$ & $9.3 \mathrm{E}-03$ & A & $\overline{0.1}$ & $\bar{Y}$ & $1.3 E \cdot 01$ & $1.2 \mathrm{E}-03$ & \begin{tabular}{|l|}
$3.3 \mathrm{E}-03$ \\
\end{tabular} & $3.0 \mathrm{E}-05$ & $\mathrm{u}$ & 0.5 & $\bar{Y}$ & $1.0 E-04$ & $9.3 E-07$ \\
\hline $\begin{array}{l}\text { 234-H Failure and } \\
\text { Oxidation of Reservoirs }\end{array}$ & $7.3 E-01$ & $\bar{U}$ & 0.5 & $\bar{N}$ & $6.1 E-02$ & $4.5 E-02$ & $6.5 E-04$ & $4.7 \mathrm{E}-04$ & EU & 2.5 & $\bar{Y}$ & $6.0 \mathrm{E}-06$ & $4.4 E-06$ \\
\hline $\begin{array}{l}\text { 232-H Pressurized Process } \\
\text { Tank Leak }\end{array}$ & $6.3 E-04$ & A & 0.1 & $\mathrm{Y}$ & $3.5 E-01$ & $2.2 E-04$ & $5.0 \mathrm{E}-02$ & $3.2 E-05$ & $\bar{U}$ & 0.5 & $\bar{Y}$ & $6.0 E-03$ & $3.8 \mathrm{E}-06$ \\
\hline 232-H Mercury Spill & $9.6 \mathrm{E}-08$ & A & 0.1 & $\bar{Y}$ & $3.5 E-01$ & $3.4 \mathrm{E}-08$ & $5.0 \mathrm{E}-02$ & $4.8 \mathrm{E}-09$ & $u$ & 0.5 & $\bar{Y}$ & $6.0 \mathrm{E}-03$ & $5.8 E-10$ \\
\hline $\begin{array}{l}\text { 232-HZ-Bed Recovery } \\
\text { System Leak }\end{array}$ & $1.8 E-01$ & $\bar{u}$ & 0.5 & $\bar{Y}$ & $3.5 E-01$ & $6.3 \mathrm{E}-02$ & $5.0 \mathrm{E}-02$ & $9.0 E-03$ & u & 0.5 & $\mathbf{Y}$ & $6.0 \mathrm{E}-03$ & $1.1 \mathrm{E}-03$ \\
\hline 233-H Process Tank Leak & $4.6 E-04$ & A & 0.1 & $\bar{Y}$ & $3.5 \mathrm{E}-01$ & $1.6 \mathrm{E}-04$ & $5.0 E-02$ & $2.3 E-05$ & A & 0.1 & $Y$ & $6.0 \mathrm{E}-03$ & $2.8 \mathrm{E}-06$ \\
\hline $\begin{array}{l}\text { 234-H Stripper System } \\
\text { Leak }\end{array}$ & $4.7 \mathrm{E}-02$ & A & 0.1 & $Y$ & $3.5 \mathrm{E}-01$ & $1.6 \mathrm{E}-02$ & $5.0 E-02$ & $2.4 E-03$ & $\bar{U}$ & 0.5 & $\bar{Y}$ & $6.0 \mathrm{E}-03$ & $2.8 \mathrm{E}-04$ \\
\hline $\begin{array}{l}\text { 232-H MTF Collapse } \\
\text { w/Fire (Seismic Event) }\end{array}$ & $6.0 E-01$ & $u$ & 0.5 & $\mathrm{~N}$ & $8.8 E-02$ & $5.3 E-02$ & $1.6 \mathrm{E}-03$ & $9.8 E-04$ & $\bar{v}$ & 0.5 & $\bar{Y}$ & $3.0 E-05$ & $1.8 E-05$ \\
\hline $\begin{array}{l}\text { 232-H MTF Collapse, } \\
\text { Failure High Risk Tanks, } \\
\text { w/Fire (Seismic Event) }\end{array}$ & $2.2 E+\infty$ & EU & 2.5 & $Y$ & $8.8 \mathrm{E}-02$ & $1.9 E-01$ & $1,6 E-03$ & $3.6 E-03$ & EU & 2.5 & $\bar{Y}$ & $3.0 \mathrm{E}-05$ & $6.6 E-05$ \\
\hline $\begin{array}{l}\text { 233-H Evaluation Basis } \\
\text { Seismic Event, No Fire }\end{array}$ & $7.2 E-03$ & $\bar{U}$ & 0.5 & $\mathbf{Y}$ & $7.0 \mathrm{EE}-02$ & $5.0 \mathrm{E}-04$ & $5.0 \mathrm{E}-03$ & $3.6 \mathrm{E}-05$ & U & 0.5 & $\bar{Y}$ & $6.0 \mathrm{E}-05$ & \begin{tabular}{|l|l|}
$4.3 E-07$ \\
\end{tabular} \\
\hline
\end{tabular}




\begin{tabular}{|c|c|c|c|c|c|c|c|c|c|c|c|c|c|}
\hline TABLE 3 & SAR Va & lues & & & Values & Creditin & SC Iten & s (includ & ing $B$ & $\overline{\text { Para }}$ & $\overline{\mathrm{ers})}$ & & \\
\hline $\begin{array}{l}\text { 233-H Evaluation Basis } \\
\text { Seismic Event w/Fire }\end{array}$ & $4.0 E+00$ & EU & 2.5 & $\mathbf{N}$ & $8.8 \mathrm{E}-02$ & $3.5 E-01$ & $1.6 \mathrm{E}-03$ & $6 . \overline{5 E-03}$ & BEU & NA & $Y$ & $3.0 E-05$ & $1.2 E-04$ \\
\hline $\begin{array}{l}\text { 234-H Building Collapse, } \\
\text { No Fire (Seismic Event) }\end{array}$ & $4.2 E-03$ & $\bar{U}$ & 0.5 & $\mathbf{Y}$ & $2.5 E-01$ & $1.0 \mathrm{E} \cdot 03$ & $2.0 \mathrm{E}-02$ & $8.4 E-05$ & $\bar{U}$ & 0.5 & $Y$ & $1.2 \mathrm{E}-03$ & $5.0 \mathrm{E}-06$ \\
\hline $\begin{array}{l}\text { 234-H Building Collapse } \\
\text { w/Fire (Seismic Event) }\end{array}$ & $2.5 E+00$ & EU & 2.5 & $\bar{N}$ & $8.8 E-02$ & $2.2 E-01$ & $1.6 \mathrm{E}-03$ & $4.1 E-03$ & EU & 2.5 & $Y$ & $3.0 \mathrm{E}-05$ & $7 . \overline{\mathrm{E}-05}$ \\
\hline & & & & & & & & & & & & & \\
\hline
\end{tabular}

TABLE 4: SAFETY CLASS, SAFETY SIGNIFICANT, AND HAZARDS ANALYSIS ITEMS

\begin{tabular}{|c|c|c|c|}
\hline EVENT & SAFETY CLASS & SAFETY SIGNIFICANT & $\begin{array}{c}\text { Additional Prevention and } \\
\text { Mitigation Features from } \\
\text { HA }\end{array}$ \\
\hline BIdg 232-H Hood Fire & $\begin{array}{l}\text { 1. Fire Suppression System } \\
\text { 2. Inventory Control Program - } \\
1 \mathrm{~kg} \text { tritium } \\
\text { 3. Facility Training Program } \\
\text { 4. Fire Protection Program }\end{array}$ & $\begin{array}{l}\text { 1. Fire Suppression System } \\
\text { 2. Inventory Control Program } \\
\text { 3. Fire Protection Program } \\
\text { 4. Ventilation Exhaust System } \\
\text { 5. Area Emergency Plan } \\
\text { 6. Structural integrity of Bldg } \\
\text { 232-H } \\
\text { 7. Structural integrity of Stack } \\
\text { 295-H }\end{array}$ & $\begin{array}{l}\text { 1. Prevention Design Features } \\
\text { A. Firewalls } \\
\text { B. Hood monitor and } \\
\text { operator response } \\
\text { 2. Mitigation Design Features } \\
\text { A. Pressure and } \\
\text { temperature monitors } \\
\text { B. Smoke detectors, } \\
\text { thermal detectors } \\
\text { C. Stack monitor }\end{array}$ \\
\hline $\begin{array}{l}\text { Bldg 232-H Multiple } \\
\text { Room/Fire Area Fire }\end{array}$ & $\begin{array}{l}\text { 1. Fire Suppression System } \\
\text { 2. Inventory Control Program - } \\
3 \mathrm{~kg} \text { tritium } \\
\text { 3. Facility Training Program } \\
\text { 4. Fire Protection Program }\end{array}$ & $\begin{array}{l}\text { 1. Facility Training Program } \\
\text { 2. Fire Protection Program } \\
\text { 3. Area Emergency Plan } \\
\text { 4. Emergency Response } \\
\text { Program }\end{array}$ & $\begin{array}{l}\text { 1. Prevention Design Features } \\
\text { A. Firewalls } \\
\text { B. Hood monitor and } \\
\text { room kannes } \\
\text { 2. Mitigation Design Features } \\
\text { A. Pressure and } \\
\text { temperature monitors } \\
\text { B. Smoke detectors, } \\
\text { thermal detectors } \\
\text { C. Stack monitor }\end{array}$ \\
\hline $\begin{array}{l}\text { Bldg 232-H Full Facility } \\
\text { Fire }\end{array}$ & $\begin{array}{l}\text { 1. Fire Suppression System } \\
\text { 2. Inventory Control Program - } \\
8 \mathrm{~kg} \text { of tritium }-3 \mathrm{~kg} \text { in } \\
\text { Process Area, } 2 \mathrm{~kg} \text { in MTF, } 3 \\
\text { kg in zeolite beds } \\
\text { 3. Facility Training Program } \\
\text { 4. Fire Protection Program }\end{array}$ & $\begin{array}{l}\text { 1. Area Emergency Plan } \\
\text { 2. Emergency Response } \\
\text { Program }\end{array}$ & $\begin{array}{l}\text { 1. Prevention Design Features } \\
\text { A. Firewalls } \\
\text { B. High temperature } \\
\text { interlock cuts power to } \\
\text { MTF life storage ovens } \\
\text { 2. Mitigation Design Features } \\
\text { A. Temperature monitors } \\
\text { B. Stack monitor } \\
\text { C. U-bed equipment } \\
\text { located in hoods of } \\
\text { ventilation system- air } \\
\text { flows through hoods to } \\
\text { stack }\end{array}$ \\
\hline Bldg 233-H Room Fire & $\begin{array}{l}\text { 1. Fire Detection and } \\
\text { Suppression System } \\
\text { 2. Inventory Control Program } \\
\text { 3. Facility Training Program } \\
\text { 4. Fire Protection Program }\end{array}$ & $\begin{array}{l}\text { 1. Facility Training Program } \\
\text { 2. Fire Protection Program } \\
\text { 3. Area Emergency Plan } \\
\text { 4. Facility Emergency Response } \\
\text { Program } \\
\text { 5. Room Air Monitoring } \\
\text { System }\end{array}$ & $\begin{array}{l}\text { 1. Prevention Design Features } \\
\text { A. Firewalls } \\
\text { 2. Mitigation Design Features } \\
\text { A. Stack monitor } \\
\text { B. Ventilation system }\end{array}$ \\
\hline $\begin{array}{l}\text { Bldg 233-H Multiple } \\
\text { Room/Fire Area Fire }\end{array}$ & $\begin{array}{l}\text { 1. Fire Detection and } \\
\text { Suppression System } \\
\text { 2. Inventory Control Program - } \\
10 \mathrm{~kg} \text { of tritium }-8.3 \mathrm{~kg} \text { in } \\
\text { fire area and } 1.7 \mathrm{~kg} \text { on } \\
\text { hydride beds } \\
\text { 3. Facility Training Program } \\
\text { 4. Fire Protection Program }\end{array}$ & $\begin{array}{l}\text { 1. Facility Training Program } \\
\text { 2. Facility Emergency Response } \\
\text { Program } \\
\text { 3. H-Area Emergency Plan } \\
\text { 4. Room Air Monitoring } \\
\text { System }\end{array}$ & $\begin{array}{l}\text { 1. Prevention Design Features } \\
\text { A. Firewalls } \\
\text { 2. Mitigation Design Features } \\
\text { A. Stack monitor } \\
\text { B. Ventilation system }\end{array}$ \\
\hline $\begin{array}{l}\text { Bldg 233-H Full Facility } \\
\text { Fire }\end{array}$ & $\begin{array}{l}\text { 1. Fire Detection and } \\
\text { Suppression System } \\
\text { 2. Inventory Control Program - } \\
15 \mathrm{~kg} \text { of tritium }-1.7 \mathrm{on} \\
\text { hydride beds and } 13.3 \mathrm{~kg} \text { in }\end{array}$ & $\begin{array}{l}\text { 1. Facility Training Program } \\
\text { 2. Facility Emergency Response } \\
\text { Program } \\
\text { 3. H-Area Emergency Plan } \\
\text { 4. Room Air Monitoring }\end{array}$ & $\begin{array}{l}\text { 1. Prevention Design Features } \\
\text { A. Firewalls } \\
\text { 2. Mitigation Design Features } \\
\text { A. Stack monitor } \\
\text { B. Ventilation system }\end{array}$ \\
\hline
\end{tabular}




\begin{tabular}{|c|c|c|c|}
\hline & $\begin{array}{l}\text { remainder of the facility } \\
\text { 3. Facility Training Program } \\
\text { 4. Fire Protection Program }\end{array}$ & System & \\
\hline $\begin{array}{l}\text { Bldg 234-H Hood Fire } \\
\text { Releasing Tritium }\end{array}$ & $\begin{array}{l}\text { 1. Fire Suppression System } \\
\text { 2. Facility Training Program } \\
\text { 3. Inventory Control Program - } \\
0.88 \mathrm{~kg} \text { tritium }\end{array}$ & $\begin{array}{l}\text { 1. Fire Suppression System } \\
\text { 2. Facility Fire Protection } \\
\text { Program } \\
\text { 3. Inventory Control Program } \\
\text { 4. Process hoods } \\
\text { 5. Ventilation Exhaust System } \\
\text { 6. Structural integrity of BIdg } \\
\text { 234-H } \\
\text { 7. Structural integrity of Stack } \\
\text { 296-H } \\
\text { 8. Area Emergency Plan }\end{array}$ & $\begin{array}{l}\text { 1. Prevention Design Features } \\
\text { A. Firewalls } \\
\text { B. Hood monitor and } \\
\text { operator response } \\
\text { 2. Mitigation Design Features } \\
\text { A. Stack monitor } \\
\text { B. Ventilation system } \\
\text { C. Smoke detectors } \\
\text { D. Thermal detectors }\end{array}$ \\
\hline $\begin{array}{l}\text { Bldg 234-H Hood Fire } \\
\text { Releasing Mercury }\end{array}$ & $\begin{array}{l}\text { 1. Fire Suppression System } \\
\text { 2. Facility Worker Training }\end{array}$ & $\begin{array}{l}\text { 1. Fire Suppression System } \\
\text { 2. Facility Fire Protection } \\
\text { Program }\end{array}$ & $\begin{array}{l}\text { 1. Mitigation Design Features } \\
\text { A. Ventilation system }\end{array}$ \\
\hline Bldg 234-H Fire Area Fire & $\begin{array}{l}\text { 1. Firewall between } 234 \mathrm{H} \text { and } \\
\text { Vault } 217 \mathrm{H} \\
\text { 2. Fire damper in the vault } \\
\text { exhaust } \\
\text { 3. Inventory Control - } \\
9.1 \mathrm{~kg} \text { of tritium and } 5 \mathrm{~kg} \text { of } \\
\text { mercury } \\
\text { 4. Facility Training Program } \\
\text { 5. Facility Fire Protection } \\
\text { Program } \\
\text { 6. Fire Suppression System }\end{array}$ & $\begin{array}{l}\text { 1. Facility Training Program } \\
\text { 2. Facility Fire Protection } \\
\text { Program } \\
\text { 3. Emergency Response Program } \\
\text { 4. Area Emergency Plan }\end{array}$ & $\begin{array}{l}\text { 1. Mitigation Design Features } \\
\text { A. Stack monitor } \\
\text { B. Ventilation system } \\
\text { C. Smoke detectors } \\
\text { D. Thermal detectors } \\
\text { E. DOT Type B shipping } \\
\text { packages }\end{array}$ \\
\hline $\begin{array}{l}\text { Bldg 234-H Vault 217-H } \\
\text { Fire (One HIVES) }\end{array}$ & $\begin{array}{l}\text { 1. Firewall between } 234 \mathrm{H} \text { and } \\
\text { Vault } 217 \mathrm{H} \\
\text { 2. Fire damper in the vault } \\
\text { exhaust } \\
\text { 3. Facility Training Program } \\
\text { 4. Facility Fire Protection } \\
\text { Program } \\
\text { 5. Combustible Loading }\end{array}$ & & $\begin{array}{l}\text { 1. Mitigation Design Features } \\
\text { A. Smoke detectors } \\
\text { B. Thermal detectors }\end{array}$ \\
\hline $\begin{array}{l}\text { Bldg 234-H Vault } 217-\mathrm{H} \\
\text { Fire }\end{array}$ & $\begin{array}{l}\text { 1. Firewall between } 234 \mathrm{H} \text { and } \\
\text { Vault } 217 \mathrm{H} \\
\text { 2. Fire damper in the vault } \\
\text { exhaust } \\
\text { 3. Facility Training Program } \\
\text { 4. Facility Fire Protection } \\
\text { Program } \\
\text { 5. Combustible Loading }\end{array}$ & & $\begin{array}{l}\text { 1. Mitigation Design Features } \\
\text { A. Smoke detectors } \\
\text { B. Thermal detectors }\end{array}$ \\
\hline $\begin{array}{l}\text { Bidg 232-H Pressurized } \\
\text { Process Tank Internal } \\
\text { Deflagration }\end{array}$ & $\begin{array}{l}\text { 1. Limit operational pressure } \\
\text { to } 3 \text { atms } \\
\text { 2. Largest tank is } 2500 \text { liters. }\end{array}$ & $\begin{array}{l}\text { 1. Limit operational pressure to } \\
\text { 3 atms } \\
\text { 2. Process Hoods } \\
\text { 3. Ventilation Exhaust System } \\
\text { 4. Structural integrity of BIdg } \\
\text { 232-H } \\
\text { 5. Structural integrity of Stack } \\
\text { 295-H }\end{array}$ & $\begin{array}{l}\text { 1. Mitigation Features } \\
\text { A. Design } \\
\text { 1. Monitors and alarms } \\
\text { 2. Kanne monitors } \\
\text { 3. Stack monitor } \\
\text { B. Administrative } \\
\text { 1. Trained personnel }\end{array}$ \\
\hline $\begin{array}{l}\text { Bldg 232-H Process Tank } \\
\text { Internal Detonation }\end{array}$ & $\begin{array}{l}\text { 1. Inventory Control Program - } \\
3 \mathrm{~kg} \text { of tritium }\end{array}$ & $\begin{array}{l}\text { 1. Controls on flammable } \\
\text { explosive mixtures (e.g., } \\
\text { routine tank sampling) } \\
\text { 2. Process Hoods } \\
\text { 3. Ventilation Exhaust System } \\
\text { 4. Structural integrity of Bldg } \\
\text { 232-H } \\
\text { 5. Structural integrity of Stack } \\
\text { 295-H } \\
\text { 6. Area Emergency Plan } \\
\text { 7. Limit operational pressure to } \\
\text { 3 atms }\end{array}$ & $\begin{array}{l}\text { 1. Prevention Features } \\
\text { A. Design } \\
\text { 1. Temperature } \\
\text { interlocks cut power } \\
\text { to heater in recovery } \\
\text { furnace if temp. rise } \\
\text { too high } \\
\text { 2. Firewalls } \\
\text { B. Administrative } \\
\text { 1. Operating procedures } \\
\text { 2. Mitigation Features } \\
\text { A. Design } \\
\text { 1. Pressure and } \\
\text { temperature monitors } \\
\text { 2. Kanne monitors } \\
\text { 3. Stack monitor } \\
\text { B. Administrative }\end{array}$ \\
\hline
\end{tabular}




\begin{tabular}{|c|c|c|c|}
\hline & & & 1. Trained personnel \\
\hline $\begin{array}{l}\text { BIdg 233-H Loading Line } \\
\text { Deflagration }\end{array}$ & $\begin{array}{l}\text { 1. Assumes maximum of } 3 \\
\text { atmospheres in mix tank } \\
\text { 2. Largest process tank is } 2000 \\
\text { liters. }\end{array}$ & $\begin{array}{l}\text { 1. Assumes maximum of } 3 \\
\text { atmospheres in mix tank } \\
\text { 2. Oxygen monitors } \\
\text { 3. Structural integrity of Bldg } \\
\text { 233-H } \\
\text { 4. Area Emergency Plan }\end{array}$ & $\begin{array}{l}\text { 1. Prevention Features } \\
\text { A. Design } \\
\text { 1. Rupture disks } \\
\text { 2. Expansion tanks } \\
\text { 3. Interlocks } \\
\text { 4. Relief tanks } \\
\text { 5. Process controls } \\
\text { (DCS) } \\
\text { 6. Nitrogen atmosphere } \\
\text { B. Administrative } \\
\text { 1. Trained personnel } \\
\text { 2. Mitigation Features } \\
\text { A. Design } \\
\text { 1. Glovebox ion } \\
\text { chamber } \\
\text { B. Administrative } \\
\text { 1. Trained personnel }\end{array}$ \\
\hline $\begin{array}{l}\text { Bldg 233-H Explosion in } \\
\text { Environmental } \\
\text { Conditioning Area }\end{array}$ & 1. Inventory Control Program & $\begin{array}{l}\text { 1. Procedures for } 0.5 \mathrm{~kg} \text { limit in } \\
\text { Room } 44 \\
\text { 2. Radiological Protection } \\
\text { Program } \\
\text { 3. Facility Training Program } \\
\text { 4. Room Air Monitoring System } \\
\text { 5. PLC and associated } \\
\text { relays/interlocks } \\
\text { 6. Design of Rm } 54 \text { electrical } \\
\text { system } \\
\text { 7. Oxygen monitors } \\
\text { 8. Structural integrity of Bldg } \\
\text { 233-H } \\
\text { 9. Area Emergency Plan } \\
\text { 10. Enclosures }\end{array}$ & $\begin{array}{l}\text { 1. Prevention Features } \\
\text { A. Design } \\
\text { 1. WR reservoir design } \\
\text { 2. Non-WR reservoirs in } \\
\text { secondary container } \\
\text { (Inerting of the test } \\
\text { equipment and } \\
\text { elimination of } \\
\text { ignition sources by } \\
\text { design and } \\
\text { procedures are being } \\
\text { considered at this } \\
\text { time } \\
\text { B. Administrative - SOPs } \\
\text { 2. Mitigation Features } \\
\text { A. Design - EC Stripper } \\
\text { system } \\
\text { B. Administrative } \\
\text { 1. Trained personnel }\end{array}$ \\
\hline $\begin{array}{l}\text { Bldg 233-H Mix Tank } \\
\text { Deflagration }\end{array}$ & $\begin{array}{l}\text { 1. Maximum operating pressure } \\
\text { of } 680 \text { torr for largest mix } \\
\text { tank of } 2000 \text { liters }\end{array}$ & $\begin{array}{l}\text { 1. Controls on OGM pressure } \\
\text { limits - Maximum operating } \\
\text { pressure of } 680 \text { torr for largest } \\
\text { mix tank } \\
\text { 2. Gloveboxes } \\
\text { 3. Jacketed pipe } \\
\text { 4. Stripper System Header } \\
\text { Piping } \\
\text { 5. Ventilation exhaust system } \\
\text { 6. Structural integrity of Bldg } \\
\text { 233-H } \\
\text { 7. Structural integrity of Bldg } \\
\text { 233-H stack } \\
\text { 8. Oxygen monitors }\end{array}$ & $\begin{array}{l}\text { 1. Prevention Design Features } \\
\text { A. Rupture disks } \\
\text { B. Interlocks } \\
\text { 2. Mitigation Features } \\
\text { A. Design } \\
\text { 1. Kanne monitors } \\
\text { 2. Expansion tanks } \\
\text { B. Administrative } \\
\text { 1. Trained personnel } \\
\text { (can divert to an } \\
\text { evacuated tank.) }\end{array}$ \\
\hline $\begin{array}{l}\text { Bldg 234-H Explosive } \\
\text { Discharge of a Reservoir }\end{array}$ & 1. Inventory Control Program & $\begin{array}{l}\text { 1. Facility Training Program } \\
\text { 2. Operating procedures for } \\
\text { reservoir unpacking } \\
\text { 3. Structural integrity of Bldg } \\
\text { 234-H } \\
\text { 4. Structural integrity of } 296-\mathrm{H} \\
\text { stack } \\
\text { 5. Ventilation exhaust system } \\
\text { 6. Process hoods }\end{array}$ & $\begin{array}{l}\text { 1. Prevention Design Features } \\
\text { A. Shorting plugs and } \\
\text { grounding } \\
\text { B. Anti-static floor/table } \\
\text { 2. Mitigation Features } \\
\text { A. Design } \\
\text { 1. Kanne monitors }\end{array}$ \\
\hline $\begin{array}{l}\text { Bldg } 234-\mathrm{H} \text { Failure and } \\
\text { Oxidation of Reservoirs }\end{array}$ & 1. Inventory Control Program & $\begin{array}{l}\text { 1. Facility Operating Procedures } \\
\text { 2. Facility Training Program } \\
\text { 3. Radiological Protection } \\
\text { Program } \\
\text { 4. Hood Monitors } \\
\text { 5. Structural integrity of Bldg } \\
\text { 234-H } \\
\text { 6. Structural integrity of Bldg } \\
\text { 234-H stack } \\
\text { 7.Ventilation exhaust system }\end{array}$ & $\begin{array}{l}\text { 1. Mitigation Design Features } \\
\text { A. Kanne monitors } \\
\text { B. Reservoir structure } \\
\text { integrity } \\
\text { C. Protective caps }\end{array}$ \\
\hline
\end{tabular}




\begin{tabular}{|c|c|c|c|}
\hline & & $\begin{array}{l}\text { 8. Operating procedures for } \\
\text { reservoir transfer } \\
\text { 9. Area Emergency Plan }\end{array}$ & \\
\hline $\begin{array}{l}\text { Bldg 232-H Pressurized } \\
\text { Process Tank Leak }\end{array}$ & $\begin{array}{l}\text { 1. Limit operational pressure } \\
\text { to } 3 \text { atms } \\
\text { 2. Largest tank is } 2500 \text { liters. }\end{array}$ & $\begin{array}{l}\text { 1. Inventory Control Program - } \\
\text { Maximum inventory of } 1.96 \\
\text { kg of tritium on largest } \\
\text { process hold tank (2500 L) at } \\
\text { a maximum pressure of } 3 \\
\text { atmospheres and } 298 \mathrm{~K} \\
\text { 2. Radiological Protection } \\
\text { Program } \\
\text { 3. Hood Monitoring System }\end{array}$ & $\begin{array}{l}\text { 1. Mitigation Design Features } \\
\text { A. Kanne monitors } \\
\text { B. Stack monitor } \\
\text { C. Ventilation system }\end{array}$ \\
\hline Bldg 232-H Mercury Spill & $\begin{array}{l}\text { 1. Inventory Control Program - } \\
\text { Maximum inventory of } 218 \\
\mathrm{~kg} \text { of mercury in Room } 164\end{array}$ & $\begin{array}{l}\text { 1. Inventory Control Program } \\
\text { 2. Building } 232-\mathrm{H} \\
\text { 3. Ventilation Exhaust System } \\
\text { 4. Stack } 295-\mathrm{H}\end{array}$ & $\begin{array}{l}\text { 1. Prevention Features } \\
\text { A. Specially designed } \\
\text { drums containing } \\
\text { tritiated mercury } \\
\text { B. Procedures } \\
\text { 2. Mitigation Features } \\
\text { A. Trained personnel }\end{array}$ \\
\hline $\begin{array}{l}\text { Bldg 232-H Z-Bed } \\
\text { Recovery System Leak }\end{array}$ & $\begin{array}{l}\text { 1. Inventory Control Program - } \\
\text { Maximum inventory of } 0.195 \\
\mathrm{~kg} \text { of tritium oxide on each of } \\
\text { two Z-Bed Recovery Systems }\end{array}$ & $\begin{array}{l}\text { 1. Building } 232-\mathrm{H} \\
\text { 2. Process Hoods } \\
\text { 3. Ventilation Exhaust System } \\
\text { 4. Stack } 295-\mathrm{H} \\
\text { 5. Area Emergency Plan }\end{array}$ & $\begin{array}{l}\text { 1. Prevention Features } \\
\text { A. Administrative - Proper } \\
\text { maintenance, inspection, } \\
\text { and operation } \\
\text { 2. Mitigation Features } \\
\text { A. Design } \\
\text { 1. Radiation alarms } \\
\text { 2. Stack monitor } \\
\text { 3. Kanne monitors } \\
\text { B. Administrative } \\
\text { 1. Trained personnel }\end{array}$ \\
\hline $\begin{array}{l}\text { Bldg 233-H Process Tank } \\
\text { Leak }\end{array}$ & $\begin{array}{l}\text { 1. Limit operational pressure } \\
\text { to } 3 \text { atms } \\
\text { 2. Largest tank is } 2000 \text { liters. }\end{array}$ & $\begin{array}{l}\text { 1. Assumes max of } 3 \\
\text { atmospheres in mix tank } \\
\text { 2. Gloveboxes } \\
\text { 3. Jacketed Piping } \\
\text { 4. Stripper System Header } \\
\text { Piping } \\
\text { 5. Ventilation Exhaust System } \\
\text { 6. Building 233-H } \\
\text { 7. Building Stack }\end{array}$ & $\begin{array}{l}\text { 1. Prevention Features } \\
\text { A. Design } \\
\text { 1. Nitrogen } \\
\text { atmosphere } \\
\text { 2. Cooling water } \\
\text { 3. Rupture disks } \\
\text { 4. Lubricating oil } \\
\text { 5. DCS } \\
\text { B. Procedures } \\
\text { 2. Mitigation Features } \\
\text { A. Design } \\
\text { 1. Kanne monitors (GB } \\
\text { ion chambers) } \\
\text { 2. Redundant } \\
\text { compressors } \\
\text { 3. Glovebox Stripper } \\
\text { System } \\
\text { B. Administrative } \\
\text { 1. Trained personnel }\end{array}$ \\
\hline $\begin{array}{l}\text { Bldg 234-H Stripper } \\
\text { System Leak }\end{array}$ & & $\begin{array}{l}\text { 1. Radiological Protection } \\
\text { Program } \\
\text { 2. Hood Monitors } \\
\text { 3. Facility Training Program }\end{array}$ & $\begin{array}{l}\text { No additional features } \\
\text { identified }\end{array}$ \\
\hline $\begin{array}{l}\text { Bldg 232-H MTF Collapse } \\
\text { With a Secondary Fire } \\
\text { (Seismic Event) }\end{array}$ & $\begin{array}{l}\text { 1. Inventory Control Program- } \\
\text { Maximum inventory of } 2 \mathrm{~kg} \\
\text { of tritium in MTF }\end{array}$ & $\begin{array}{l}\text { 1. Inventory Control Program } \\
\text { 2. Emergency Response Program } \\
\text { 3. Facility Training Program } \\
\text { 4. Area Emergency Plan }\end{array}$ & $\begin{array}{l}\text { 1. Prevention Design Features } \\
\text { A. Reinforced concrete } \\
\text { building structure } \\
\text { B. Flammable material } \\
\text { control program }\end{array}$ \\
\hline $\begin{array}{l}\text { Bldg 232-H MTF Collapse } \\
\text { \& Failure of High Risk } \\
\text { Process Tanks W/ } \\
\text { Secondary Fire (Seismic } \\
\text { Event) }\end{array}$ & $\begin{array}{l}\text { 1. Inventory Control Program - } \\
\text { Inventory limited to } 3 \mathrm{~kg} \text { of } \\
\text { tritium oxide in Z-beds, } 3 \mathrm{~kg} \\
\text { of tritium in Process Area, } 2 \\
\mathrm{~kg} \text { of tritium in MTF }\end{array}$ & $\begin{array}{l}\text { 1. Emergency Response Program } \\
\text { 2. Facility Training Program } \\
\text { 3. Area Emergency Plan }\end{array}$ & $\begin{array}{l}\text { 1. Prevention Design Features } \\
\text { A. Reinforced concrete } \\
\text { building structure }\end{array}$ \\
\hline $\begin{array}{l}\text { Bldg 233-H Evaluation } \\
\text { Basis Seismic Event, No } \\
\text { Fire }\end{array}$ & $\begin{array}{l}\text { 1. Inventory Control Program - } \\
15 \mathrm{~kg} \text { of tritium in building }\end{array}$ & $\begin{array}{l}\text { 1. Inventory Control Program } \\
\text { 2. Emergency Response Program } \\
\text { 3. Facility Training Program }\end{array}$ & $\begin{array}{l}\text { 1. Prevention Design Features } \\
\text { A. Reinforced concrete } \\
\text { building structure } \\
\text { 2.Mitigation Design Features } \\
\text { A. Seismic Tritium } \\
\text { Confinement System }\end{array}$ \\
\hline
\end{tabular}




\begin{tabular}{|c|c|c|c|}
\hline & & & (STCS) \\
\hline $\begin{array}{l}\text { Bldg 233-H Evaluation } \\
\text { Basis Seismic Event, Fire }\end{array}$ & $\begin{array}{l}\text { 1. Inventory Control Program - } \\
15 \mathrm{~kg} \text { of tritium in building }\end{array}$ & $\begin{array}{l}\text { 1. Emergency Response } \\
\text { Program } \\
\text { 2. Facility Training Program } \\
\text { 3. Area Emergency Plan }\end{array}$ & $\begin{array}{l}\text { 1. Mitigation Design Features } \\
\text { A. Building 233-H } \\
\text { B. Seismic Tritium } \\
\text { Confinement System } \\
\text { (STCS) } \\
\text { C. Mix Tanks A-G } \\
\text { D. Flowthrough Beds A\&B } \\
\text { E. TCAP Feed Beds A\&B } \\
\text { F. TCAP Product Beds } \\
\text { A\&B } \\
\text { G. P-Evac Recovery Beds } \\
\text { A-D } \\
\text { H. Flammable material } \\
\text { control progran } \\
\text { (including fire retardant } \\
\text { material) }\end{array}$ \\
\hline $\begin{array}{l}\text { Bldg 234-H Building } \\
\text { Collapse, No Fire (seismic } \\
\text { Event) }\end{array}$ & $\begin{array}{l}\text { 1. Inventory Control Program - } \\
\text { Inventory outside vault is } \\
\text { limited to } 9.1 \mathrm{~kg} \text { of tritium } \\
\text { 2. HIVES }\end{array}$ & $\begin{array}{l}\text { 1. Inventory Control Program } \\
\text { 2. HIVES } \\
\text { 3. Emergency Response Program } \\
\text { 4. Facjlity Training Program }\end{array}$ & $\begin{array}{l}\text { 1. Prevention Design Features } \\
\text { A. Building structure }\end{array}$ \\
\hline $\begin{array}{l}\text { Bldg 234-i Building } \\
\text { Collansi, Secondary Fires } \\
\text { (Seismic Event) }\end{array}$ & $\begin{array}{l}\text { 1. Inventory Control Program - } \\
\text { Inventory outside vault is } \\
\text { limited to } 9.1 \mathrm{~kg} \text { of tritium } \\
\text { 2. Firewall }\end{array}$ & $\begin{array}{l}\text { 1. Emergency Response Program } \\
\text { 2. Facility Training Program } \\
\text { 3. Area Emergency Plan }\end{array}$ & $\begin{array}{l}\text { 1. Prevention Design Features } \\
\text { A. Building structure } \\
\text { 2. Mitigation Design Features } \\
\text { A. HIVES } \\
\text { B. Flammable material } \\
\text { control program }\end{array}$ \\
\hline
\end{tabular}




\begin{tabular}{|c|c|c|c|}
\hline & & & (STCS) \\
\hline $\begin{array}{l}\text { Bldg 233-H Evaluation } \\
\text { Basis Seismic Event, Fire }\end{array}$ & $\begin{array}{l}\text { 1. Inventory Control Program - } \\
15 \mathrm{~kg} \text { of tritium in building }\end{array}$ & $\begin{array}{l}\text { 1. Emergency Response } \\
\text { Program } \\
\text { 2. Facility Training Program } \\
\text { 3. Area Emergency Pian }\end{array}$ & $\begin{array}{l}\text { 1. Mitigation Design Features } \\
\text { A. Building 233-H } \\
\text { B. Seismic Tritium } \\
\text { Confinement System } \\
\text { (STCS) } \\
\text { C. Mix Tanks A-G } \\
\text { D. Flowthrough Beds A\&B } \\
\text { E. TCAP Feed Beds A\&B } \\
\text { F. TCAP Product Beds } \\
\text { A\&B } \\
\text { G. P-Evac Recovery Beds } \\
\text { A-D } \\
\text { H. Flammable material } \\
\text { control program } \\
\text { (including fire retardant } \\
\text { material) }\end{array}$ \\
\hline $\begin{array}{l}\text { Bldg } 234-\mathrm{H} \text { Building } \\
\text { Collapse, No Fire (Seismic } \\
\text { Event) }\end{array}$ & $\begin{array}{l}\text { 1. Inventory Control Program - } \\
\text { Inventory outside vault is } \\
\text { limited to } 9.1 \mathrm{~kg} \text { of tritium } \\
\text { 2. HVES }\end{array}$ & $\begin{array}{l}\text { 1. Inventory Control Program } \\
\text { 2. HIVES } \\
\text { 3. Emergency Response Program } \\
\text { 4. Facility Training Program }\end{array}$ & $\begin{array}{l}\text { 1. Prevention Design Features } \\
\text { A. Building structure }\end{array}$ \\
\hline $\begin{array}{l}\text { Bldg 234-i Building } \\
\text { Collarsi, Secondary Fires } \\
\text { (Seismic Event) }\end{array}$ & $\begin{array}{l}\text { 1. Inventory Control Program - } \\
\text { Inventory outside vault is } \\
\text { limited to } 9.1 \mathrm{~kg} \text { of tritium } \\
\text { 2. Firewall }\end{array}$ & $\begin{array}{l}\text { 1. Emergency Response Program } \\
\text { 2. Facility Training Program } \\
\text { 3. Area Emergency Plan }\end{array}$ & $\begin{array}{l}\text { 1. Prevention Design Features } \\
\text { A. Building structure } \\
\text { 2. Mitigation Design Features } \\
\text { A. HIVES } \\
\text { B. Flammable material } \\
\text { control program }\end{array}$ \\
\hline
\end{tabular}

